\title{
Dynamics of cellular immune responses in the acute phase of dengue virus infection.
}

\section{$\operatorname{AUTHOR}(\mathrm{S})$ :}

Yoshida, Tomoyuki; Omatsu, Tsutomu; Saito, Akatsuki; Katakai, Yuko; Iwasaki, Yuki; Kurosawa, Terue; Hamano, Masataka; ... Yasutomi, Yasuhiro; Kurane, Ichiro; Akari, Hirofumi

\section{CITATION:}

Yoshida, Tomoyuki ... [et al]. Dynamics of cellular immune responses in the acute phase of dengue virus infection.. Archives of virology 2013, 158(6): 1209-1220

\section{ISSUE DATE:}

2013-06

URL:

http://hdl.handle.net/2433/189758

\section{RIGHT:}

The final publication is available at Springer via http://dx.doi.org/10.1007/s00705-0131618-6; この論文は著者最終稿です。内容が印刷版と異なることがありますので、引用 の際には出版社版をご確認ご利用ください。This is the Accepted Author Manuscript. Please cite only the published version. 
Original Article

2 Dynamics of cellular immune responses in the acute phase of dengue virus

3 infection

4

5

6 Tomoyuki Yoshida, Tsutomu Omatsu, Akatsuki Saito, Yuko Katakai, Yuki

7 Iwasaki, Terue Kurosawa, Masataka Hamano, Atsunori Higashino, Shinichiro

8 Nakamura, Tomohiko Takasaki, Yasuhiro Yasutomi, Ichiro Kurane and Hirofumi

9 Akari

10

11 T. Yoshida $\cdot$ Y. Iwasaki · T. Kurosawa $\cdot$ M. Hamano $\cdot$ Y. Yasutomi $\cdot$ H. Akari

12 Tsukuba Primate Research Center, National Institute of Biomedical Innovation, 1-1

13 Hachimandai, Tsukuba, Ibaraki 305-0843, Japan

15 T. Yoshida (E-mail) A A. Saito $\cdot$ A. Higashino $\cdot$ H. Akari (E-mail)

16 Center for Human Evolution Modeling Research, Primate Research Institute, Kyoto

17 University, Inuyama, Aichi 484-8506, Japan

18 E-mail: yoshida.tomoyuki.4w@kyoto-u.ac.jp

19 H. Akari

20 E-mail: akari.hirofumi.5z@kyoto-u.ac.jp

21

22 T. Omatsu $\cdot$ T. Takasaki $\cdot$ I. Kurane

23 Department of Virology I, National Institute of Infectious diseases, 1-23-1 Toyama,

24 Shinjuku-ku, Tokyo 162-8640, Japan

25

26 A. Saito

27 International Research Center for Infectious Diseases, The Institute of Medical Science,

28 The University of Tokyo, 4-6-1 Shirokanedai, Minato-ku, Tokyo 108-8639, Japan

29

30 Y. Katakai $\cdot$ M. Hamano

31 Corporation for Production and Research of Laboratory Primates, 1-1 Hachimandai, 
32 Tsukuba, Ibaraki 305-0843, Japan

33

34 S. Nakamura

35 Research Center for Animal Life Science, Shiga University of Medical Science, Seta

36 Tsukinowa-cho, Otsu, Shiga 520-2192, Japan

37

38 *Address corresponding: T. Yoshida, Primate Research Institute, Kyoto University, 39 Inuyama, Aichi 484-8506, Japan.

40 E-mail: yoshida.tomoyuki.4w@kyoto-u.ac.jp

41

42 *Address corresponding: H. Akari, Primate Research Institute, Kyoto University, 43 Inuyama, Aichi 484-8506, Japan.

44 E-mail: akari.hirofumi.5z@kyoto-u.ac.jp

45

46 T. Yoshida and T. Omatsu contributed equally to this study.

47 Key words: Dengue virus, marmoset, CD4, CD8.

48 


\section{Abstract}

49 In this study we sought to examine the dynamics of cellular immune responses in the

50 acute phase of dengue virus (DENV) infection in a marmoset model. Here we found

51 that the DENV infection in marmosets greatly induced responses of CD4/CD8 central

52 memory $\mathrm{T}$ and NKT cells. Interestingly, the strength of the immune responses were

53 greater in the animals infected with a dengue fever strain than those with a dengue 54 hemorrhagic fever strain of DENV. In contrast, at the re-challenge of the same DENV 55 strain as a primary infection, a neutralizing antibody induced likely played a critical role 56 in sterilizing inhibition against the viral replication, resulting in strong but delayed 57 responses of CD4/CD8 central memory T and NKT cells. Our results in this study may 58 help better understand the dynamics of cellular and humoral immune responses in the 59 control of DENV infection. 
62 DENV causes the most prevalent arthropod-borne viral infections in the world [29].

63 Infection with one of the four serotypes of DENV will lead to dengue fever (DF) and 64 sometimes the fatal dengue hemorrhagic fever (DHF) or dengue shock syndrome (DSS) 65 [12]. The serious diseases likely develop more frequently following secondary infection 66 with a serotype of DENV different from that of the primary infection. Infection with 67 DENV induces a high-titered neutralizing antibody that can provide long-term 68 immunity to the homologous DENV serotype while the effect of the antibody on the 69 heterologous serotypes is transient [22]. On the other hand, enhanced pathogenicity 70 after secondary DENV infection appears to be explained by antibody dependent enhancement (ADE): mouse and monkey experiments have shown that sub-neutralizing levels of DENV-specific antibodies actually enhance infection $[1,6,11]$. Thus, development of an effective tetravalent dengue vaccine is considered to be of public health priority. There are recently several vaccine candidates for DENV infection under clinical trials, and most of them target the induction of neutralizing antibodies [20].

Research of the long-term immune response in humans has provided several interesting parallels to the data. It was reported that complete cross-protective immunity from heterologous challenge was induced in individuals 1-2 months after a primary DENV infection, with partial immunity present up to 9 months resulting in a milder disease of shorter duration on reinfection, and that complete serotype-specific immunity against symptomatic dengue was observed up to 18 months post-infection [30]. Guzman and Sierra have previously recorded the long-term presence of both DENV-specific antibodies and T cells up to 20 years after natural infections [10, 31]. Of note, increased

$84 \mathrm{~T}$ cell activation is reportedly associated with severe dengue disease $[7,8]$. Thus, the 85 balance between humoral and cellular immunity may be important in the control of 86 dengue diseases.

However, the detail regarding the implication of humoral and cellular immunity in controlling DENV infection remains to be elucidated. Previously, passive transfer of 89 either monoclonal or polyclonal antibodies was shown to protect against homologous 90 DENV challenge $[13,15,16]$. It was also reported that neutralizing antibodies played a 91 greater role than cytotoxic T lymphocytes (CTL) responses in heterologous protection 92 against secondary DENV infection in vivo in IFN- $\alpha / \beta \mathrm{R}^{-/-}$and IFN $\gamma \mathrm{R}^{-/-}$mouse models 
93 [18]. Moreover, $\mathrm{CD}^{+}{ }^{\mathrm{T}}$ cell depletion did not affect the DENV-specific IgG or IgM Ab 94 titers or their neutralizing activity in the IFN $\gamma \mathrm{R}^{-/-}$mouse model [36]. On the other hand,

95 there are several reports showing that cellular immunity rather than humoral immunity 96 plays an important role in the clearance of DENV. For example, in adoptive transfer 97 experiments, although cross-reactive DENV-1-specific $\mathrm{CD}^{+} \mathrm{T}$ cells did not mediate 98 protection against a DENV-2 lethal infection, adoptive transfer of $\mathrm{CD} 4^{+} \mathrm{T}$ cells alone 99 mediated protection and delayed mortality in IFN- $\alpha / \beta \mathrm{R}^{-/-}$and IFN $\gamma \mathrm{R}^{-/-}$mouse models 100 [39]. It has also been demonstrated that $\mathrm{CD}^{+} \mathrm{T}$ lymphocytes have a direct role in 101 protecting DENV challenge in the IFN- $\alpha / \beta \mathrm{R}^{-/-}$mouse model of DENV infection by 102 depleting $\mathrm{CD}^{+} \mathrm{T}$ cells [35]. In addition, previous data from adoptive-transfer 103 experiments in BALB/c mice showed that cross-reactive memory $\mathrm{CD}^{+} \mathrm{T}$ cells were 104 preferentially activated by the secondary DENV infection, resulting in augmented IFN- $\gamma$ 105 and tumor necrosis factor- $\alpha$ (TNF- $\alpha)$ responses, and that this effect was 106 serotype-dependent [2,3]. Although it has previously been suggested that inducing 107 neutralizing antibodies against DENV may play an important role in controlling DENV infection, CTL are also proposed to contribute to clearance during primary DENV infection and in pathogenesis during secondary heterologous infection in the BALB/c mouse model [4].

111 Why did the mouse models in DENV infection show inconsistent results in 112 vivo? One of the reasons could be that these results were obtained mainly from 113 genetically manipulated mice such as the IFN- $\alpha / \beta \mathrm{R}^{-/-}$and $\mathrm{IFN} \gamma \mathrm{R}^{-/-}$mice. Moreover, 114 these mice were inoculated with $10^{9}-10^{10}$ genome equivalents (GE) of DENV [27, 35, $11536]$, which were likely large excess as compared with humans injected with $10^{4}-10^{5} \mathrm{GE}$ 116 of DENV by a mosquito [19]. In addition, efficiency of DENV replication in wild mice 117 in vivo was very low compared with humans [35].

118 Recently, novel non-human primate models of DENV infection using rhesus 119 macaques as well as marmosets and tamarins have been developed [24-26, 38]. An 120 intravenous challenge of rhesus macaques with a high dose of virus inoculum $\left(1 \times 10^{7}\right.$ $121 \mathrm{GE)}$ of DENV-2 resulted in readily visible hemorrhaging, which is one of the cardinal 122 symptoms of human DHF [26]. It was also shown that the cellular immune response 123 was activated due to expression of IFN- $\gamma$, TNF- $\alpha$, and macrophage inflammatory 124 protein-1 $\beta$ in $\mathrm{CD}^{+}$and $\mathrm{CD}^{+} \mathrm{T}$ cells during primary DENV infection in rhesus 125 macaques [20]. On the other hand, in the marmoset model of DENV infection, we 
126 observed high levels of viremia $\left(10^{5}-10^{7} \mathrm{GE} / \mathrm{ml}\right)$ after subcutaneous inoculation with

$12710^{4}-10^{5}$ plaque forming unit (PFU) of DENV-2. Moreover, we demonstrated that 128 DENV-specific IgM and IgG were consistently detected, and that the DENV-2 genome 129 was not detected in any of these marmosets inoculated with the same DENV-2 strain as 130 the primary infection [24]. It is notable that while neutralizing antibody titers were at 131 levels of 1:20-1:80 before the re-challenge inoculation, the titers increased up to 132 1:160-1:640 after the re-challenge inoculation [24]. These results suggested that the 133 secondary infection with DENV-2 induced a protective humoral immunity to DENV-2, 134 and that DENV-infected marmoset models may be useful in order to analyze the 135 relationship between DENV replication and dynamics of adaptive immune responses in 136 vivo.

137 Taking these findings into consideration, we sought to investigate the dynamics 138 of cellular immunity in response toward primary and secondary DENV infection in the 139 marmoset model.

140 


\section{Animals}

143 All animal studies were conducted in accordance with the protocols of experimental 144 procedures that were approved by the Animal Welfare and Animal Care Committee of 145 the National Institute of Infectious Diseases, Japan, and the National Institute of 146 Biomedical Innovation, Japan. A total of 6 male marmosets, weighing 258-512 g, were 147 used. Common marmosets were purchased from Clea Japan Inc. (Tokyo, Japan), and 148 caged singly at $27 \pm 2{ }^{\circ} \mathrm{C}$ in $50 \pm 10 \%$ humidity with a $12 \mathrm{~h}$ light-dark cycle (lighting from 149 7:00 to 19:00) at Tsukuba Primate Research Center, National Institute of Biomedical 150 Innovation, Tsukuba, Japan. Animals were fed twice a day with a standard marmoset 151 diet (CMS-1M, CLEA Japan) supplemented with fruit, eggs and milk. Water was given 152 ad libitum. The animals were in a healthy condition and confirmed to be negative for 153 anti-dengue virus antibodies before inoculation with dengue virus [24].

\section{Cells}

156 Cell culture was performed as previously described [24]. Vero cells were cultured in 157 Minimum Essential Medium (MEM, Sigma) with $10 \%$ heat-inactivated fetal bovine 158 serum (FBS, GIBCO) and $1 \%$ non-essential amino acid (NEAA, Sigma) at $37{ }^{\circ} \mathrm{C}$ in $5 \%$ $159 \mathrm{CO}_{2}$. C6/36 cells were cultured in MEM with $10 \% \mathrm{FBS}$ and $1 \%$ NEAA at $28{ }^{\circ} \mathrm{C}$ in $5 \%$ $160 \quad \mathrm{CO}_{2}$.

\section{Virus}

163 DENV type 2 (DENV-2), DHF0663 strain (Accession no. AB189122) and $164 \mathrm{D} 2 / \mathrm{Hu} /$ Maldives/77/2008NIID (Mal/77/08) strain were used for inoculation studies. 165 The DENV-2, DHF0663 strain was isolated from a DHF case in Indonesia. The 166 DENV-2, Mal/77/08 strain was isolated from imported DF cases from Maldives. All 167 DENV strains isolated clinical samples were propagated with $\mathrm{C} 6 / 36$ cells and were used 168 within 4 passages on $\mathrm{C} 6 / 36$ cells. Culture supernatant from infected $\mathrm{C} 6 / 36$ cells was 169 centrifuged at $3,000 \mathrm{rpm}$ for $5 \mathrm{~min}$ to remove cell debris, and then stored at $-80{ }^{\circ} \mathrm{C}$ until 170 use. 
173 In the challenge experiments, the profiling of the key adaptive and innate immune cells

174 in the marmosets after infection with serotype 2 of DENV (DENV-2) was examined. At

175 the primary DENV infection, four marmosets were inoculated subcutaneously in the

176 back with either $1.9 \times 10^{5}$ PFU of the DENV-2 Mal/77/08 strain (Cj08-007, Cj07-011)

177 or $1.8 \times 10^{4}$ PFU of the DHF0663 strain (Cj07-006, Cj07-008) [24]. In the case of the

178 DENV re-challenge experiment, two marmosets initially inoculated with $1.8 \times 10^{5} \mathrm{PFU}$

179 of the DHF0663 strain were re-inoculated 33 weeks after the primary challenge with

$1801.8 \times 10^{5}$ PFU of the same strain (Cj07-007, Cj07-014) [24]. Blood samples were

181 collected on days $0,1,3,7,14$, and 21 after inoculation and were used for virus titration

182 and flow cytometric analysis. Inoculation with DENV and blood drawing was

183 performed under anesthesia with $5 \mathrm{mg} / \mathrm{kg}$ of ketamine hydrochloride. Day 0 was

184 defined as the day of virus inoculation. The viral loads in marmosets obtained in a

185 previous study were shown in Supplementary Figure 1 [24].

\section{Flow cytometry}

188 Flow cytometry was performed as previously described [37]. Fifty microliters of whole

189 blood from marmosets was stained with combinations of fluorescence-conjugated

190 monoclonal antibodies; anti-CD3 (SP34-2; Becton Dickinson), anti-CD4 (L200; BD

191 Pharmingen), anti-CD8 (CLB-T8/4H8; Sanquin), anti-CD16 (3G8; BD Pharmingen),

192 anti-CD95 (DX2; BD Pharmingen), and anti-CD62L (145/15; Miltenyi Biotec). Then,

193 erythrocytes were lysed with FACS lysing solution (Becton Dickinson). After washing

194 with a sample buffer containing phosphate-buffered saline (PBS) and 1\% fetal calf

195 serum (FCS), the labeled cells were resuspended in a fix buffer containing PBS and 1\%

196 formaldehyde. The expression of these markers on the lymphocytes was analyzed with

197 FACSCanto II flow cytometer (Becton Dickinson). The data analysis was conducted

198 using a FlowJo software (Treestar, Inc.). Results were shown as mean \pm standard

199 deviation (SD) from the marmosets used in this study. 


\section{Results}

201

202 Naïve, central/effector memory $\mathbf{T}$ cells and NK/NKT cells in marmosets

203 Basic information regarding CD4/CD8 naïve and central/effector memory T cells and

204 NK/NKT cells in common marmosets was unavailable. Thus, we examined the

205 immunophenotypes of lymphocyte subsets in the marmosets (Fig. 1). The gating

206 strategy for profiling the CD4 and CD8 T cells in the marmosets by FACS is shown in

207 Figure 1a. Human T cells are classically divided into 3 functional subsets based on their

208 cell surface expression of CD62L and CD95, i.e. CD62 $\mathrm{L}^{+} \mathrm{CD} 95^{-}$naive $\mathrm{T}$ cells $\left(\mathrm{T}_{\mathrm{N}}\right)$,

$209 \mathrm{CD} 62 \mathrm{~L}^{+} \mathrm{CD} 95^{+}$central memory $\mathrm{T}$ cells $\left(\mathrm{T}_{\mathrm{CM}}\right)$, and CD62L ${ }^{-} \mathrm{CD} 95^{ \pm}$effector memory $\mathrm{T}$

210 cells $\left(\mathrm{T}_{\mathrm{EM}}\right)[9,21,28]$. In this study, $\mathrm{CD} 4^{+}$and $\mathrm{CD} 8^{+} \mathrm{T}_{\mathrm{N}}, \mathrm{T}_{\mathrm{CM}}$, and $\mathrm{T}_{\mathrm{EM}}$ subpopulations

211 were defined as CD62 $\mathrm{L}^{+} \mathrm{CD} 95^{-}, \mathrm{CD} \mathrm{L}^{+} \mathrm{CD}^{+} 5^{+}$, and CD62L-CD95 ${ }^{ \pm}$, respectively (Fig.

212 1a and Table 1). The average ratio of $\mathrm{CD}^{+} \mathrm{T}$ lymphocytes in the total lymphocytes of 3

213 marmosets was found to be $75.7 \pm 6.4 \%$. The average ratio of $\mathrm{CD}^{+} \mathrm{T}$ cells in the $\mathrm{CD} 3^{+}$

214 subset was $65.4 \pm 6.8 \%$. The average ratios of $\mathrm{CD}^{+} \mathrm{T}_{\mathrm{N}}, \mathrm{T}_{\mathrm{CM}}$, and $\mathrm{T}_{\mathrm{EM}}$ cells were

$21565.9 \pm 3.7 \%, 16.4 \pm 2.9 \%, 19.5 \pm 2.5 \%$, respectively. The average ratio of $\mathrm{CD}^{+} \mathrm{T}$ cells in

216 the $\mathrm{CD}^{+}$subset was $29.0 \pm 8.0 \%$. The average ratios of $\mathrm{CD}^{+} \mathrm{T}_{\mathrm{N}}, \mathrm{T}_{\mathrm{CM}}$, and $\mathrm{T}_{\mathrm{EM}}$ cells

217 were $66.7 \pm 10.2 \%, 4.7 \pm 3.6 \%, 28.8 \pm 14.8 \%$, respectively.

218 We recently characterized a $\mathrm{CD} 16^{+}$major NK cell subset in tamarins and

219 compared NK activity in tamarins with or without DENV infection [37, 38]. In terms of

220 NKT cells, NK1.1 (CD161) and CD1d are generally used as markers of NKT cells [32].

221 However, so far these anti-human NK1.1 and CD1d antibodies are unlikely to

222 cross-react with the NKT cells of the marmosets. Thus, we defined NKT cells as a

223 population expressing both CD3 and CD16 as previously reported $[14,17]$. The NK and

224 NKT cell subsets were determined to be $\mathrm{CD} 3^{-} \mathrm{CD} 16^{+}$and $\mathrm{CD}^{+} \mathrm{CD} 16^{+}$lymphocytes in

225 the marmosets. The average ratios of NK and NKT cell subsets in the lymphocytes were

$2264.2 \pm 2.6 \%$ and $5.1 \pm 3.4 \%$, respectively (Table 1 ). We observed that the proportions of the

227 major lymphocyte subsets in the marmosets were similar to those in cynomolgus

228 monkeys and tamarins [37, 38].

230 Profiling of CD4 and CD8 T, NK and NKT cells in the marmosets infected with

231 primary DENV-2 (Mal/77/08 strain)

232 We investigated the cellular immune responses against DENV-2 DF strain (Mal/77/08) 
233 in marmosets. Dengue vRNA was detected in plasma samples from two marmosets on

234 day 2 post-infection (Supplementary Fig. 1a). For each of the two marmosets (Cj08-007,

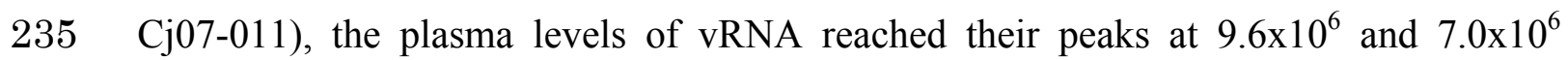
$236 \mathrm{GE} / \mathrm{ml}$ on day 4 post-infection, respectively. The plasma vRNA was detected in both 237 marmosets on days 2, 4, and 7. We then examined the profiling and frequencies of the 238 CD4 and CD8 T, NK and NKT cells in the infected marmosets (Figs. 2-3 and Table 2). $239 \mathrm{CD}^{+} \mathrm{T}_{\mathrm{CM}}$ cells drastically increased to $88.7 \pm 2.8 \%$ from $13 \pm 0.4 \%$ between day 0 and 240 day 2 post-inoculation (Table 2). Reciprocally, $\mathrm{CD}^{+} \mathrm{T}_{\mathrm{N}}$ cells completely decreased to $2411.6 \pm 3.3 \%$ from $74.1 \pm 0.9 \%$ at the same time. $\mathrm{CD}^{+} \mathrm{T}_{\mathrm{EM}}$ cells maintained the initial 242 levels throughout the observation periods. $\mathrm{CD}^{+} \mathrm{T}_{\mathrm{CM}}$ cells increased to $91.9 \pm 5.5 \%$ from $2432.1 \pm 0.8 \%$ between day 0 day 2 post-inoculation, and reciprocally $\mathrm{CD}^{+} \mathrm{T}_{\mathrm{N}}$ cells 244 decreased to $2.5 \pm 4.7 \%$ from $89.9 \pm 2.5 \%$ at the same time. In addition, NK cells 245 maintained their initial levels throughout the observation periods. However, NKT cells 246 drastically increased to $52.6 \pm 17 \%$ from $0.2 \pm 0.0 \%$ between day 0 and day 2 247 post-inoculation. These results suggest that CD4/CD8 T and NKT cells may efficiently 248 respond to the Mal/77/08 strain of DENV.

249

250 Profiling of CD4 and CD8 T, NK and NKT cells in the marmosets infected with primary DENV-2 (DHF0663 strain)

252 Next, we investigated the cellular immune responses against another DENV-2 DHF 253 strain (DHF0663) in marmosets. Dengue vRNA was detected in plasma samples from the marmosets on day 2 post-infection ([24], Supplementary Fig. 1b). For each of the two marmosets (Cj07-006, Cj07-008), the plasma vRNA levels were shown to be $3.4 \times 10^{5}$ and $3.8 \times 10^{5} \mathrm{GE} / \mathrm{ml}$ on day 2 and $2.0 \times 10^{6}$ and $9.4 \times 10^{5} \mathrm{GE} / \mathrm{ml}$ at the peak on day 4 post-infection, respectively, followed by being undetectable on day 14 . Thus, we examined the profiling and frequencies of the $\mathrm{CD} 4^{+}$and $\mathrm{CD} 8^{+} \mathrm{T}, \mathrm{NK}$ and NKT cells in these DENV-infected marmosets (Fig. 4-5 and Table 3). It was found that on day 7 post-inoculation $\mathrm{CD}^{+}$and $\mathrm{CD} 8^{+} \mathrm{T}_{\mathrm{N}}$ cells decreased and in contrast the $\mathrm{T}_{\mathrm{CM}}$ populations increased in both marmosets, however, the changes in proportion were much less than

262 the case of the marmosets infected with the DF strain. We observed no consistent 263 tendency in the kinetics of $\mathrm{CD}^{+}$and $\mathrm{CD} 8^{+} \mathrm{T}_{\mathrm{EM}}$ cells nor in NK and NKT cells. These 264 results suggest that the strength of $\mathrm{T}$ cell responses may be dependent on the strain of 265 DENV. 
267 Profiling of CD4 and CD8 T, NK and NKT cells in the marmosets re-challenged

\section{8 with a DENV-2 strain}

269 In order to examine the cellular immune responses against the re-challenge of DENV-2

270 DHF strain in marmoset model, marmosets were infected twice with the same DENV-2

271 strain (DHF0663) at 33 weeks interval after the primary infection. The results showed

272 that vRNA and NS1 antigens were not detected in plasma and that the neutralizing

273 antibody titer was obviously increased after the secondary infection. The data indicated

274 that the primary infection induced protective immunity including a neutralizing 275 antibody to the re-challenge of the same DENV strain ([24]; Supplementary Fig.1c). We 276 also investigated the profiling of the CD4 and CD8 T, NK and NKT cells in the 277 marmosets (Cj07-007, Cj07-014) re-challenged with the same DENV-2 strain 278 (DHF0663) (Fig. 6-7). $\mathrm{CD}^{+} \mathrm{T}_{\mathrm{CM}}$ cells drastically increased on day 14 post-inoculation. 279 On the other hand, $\mathrm{CD}^{+} \mathrm{T}_{\mathrm{N}}$ cells completely decreased at the same time. $\mathrm{CD} 4^{+} \mathrm{T}_{\mathrm{EM}}$ 280 cells maintained their initial levels through the observation periods. Similarly $\mathrm{CD} 8^{+} \mathrm{T}_{\mathrm{CM}}$ 281 and NKT cells clearly increased on day 14 post-inoculation. Importantly, these T cell responses were induced one week after the obvious induction of the neutralizing antibody in the marmosets [24]. These results suggest that the neutralizing antibody may play a critical role in the complete inhibition of the secondary DENV infection. 


\section{Discussion}

286

287 In this study, we demonstrated the dynamics of the central/effector memory $\mathrm{T}$ cells and

288 NK/NKT subsets against DENV infection in our marmoset model. First, we

289 characterized the central/effector memory $\mathrm{T}$ and NK/NKT subsets in marmosets (Fig. 1).

290 Second, we found that CD4/CD8 central memory T cells and NKT cells had significant

291 responses in the primary DENV infection and the levels were likely to be dependent on

292 the strain of the virus employed for challenge experiments (Fig. 2-5). Finally, we found

293 delayed responses of CD4/CD8 central memory T cells in the monkeys re-challenged

294 with the same DENV DHF strain, irrespective of the complete inhibition of the DENV

295 replication. (Fig. 6-7).

296 The present study shed light on the dynamics of cellular and humoral immune responses against DENV in vivo in the marmoset model. Our results showed that cellular immune responses were induced earlier than that of antibody responses in the primary infection. Thus, our results suggest the possibility that cellular immunity may contribute, at least in part, to the control of primary DENV infection. On the other hand, in the presence of neutralizing antibodies in the re-challenged monkeys [24], delayed (on day14 after the re-challenge) responses of CD4/CD8 central memory $\mathrm{T}$ cells were observed irrespective of the complete inhibition of the DENV replication. These results indicate that the cellular immunity is unlikely to play a major role in the control of the DENV re-infection. Alternatively, it is still possible that cellular immunity, such as memory $\mathrm{T}$ cells, could partially play a helper role for the enhanced induction of neutralizing antibodies even without an apparent increase in the proportion of $\mathrm{T}_{\mathrm{CM}}$, resulting in efficient prevention of DENV replication.

It is possible that the DENV strains used in this study may influence the strength

310 of cellular immune responses. The differences in cellular immune responses between 311 the monkeys infected with the DF or DHF strain may not be caused by individual 312 differences in marmosets because the FACS results were consistent with each 2 313 marmosets. It was previously shown that there was a reduction in CD3, CD4, and CD8 314 cells in DHF and demonstrated that lower levels of CD3, CD4, and CD8 cells 315 discriminated DHF from DF patients during the febrile stage of illness [5]. There was a 316 significant increase in an early activation marker on $\mathrm{CD}^{+} \mathrm{T}$ cells in children with DHF 317 compared with DF during the febrile period of illness [8]. Another group reported that 
318 levels of peripheral blood mononuclear cell apoptosis were higher in children 319 developing DHF [23]. Moreover, cDNA array and ELISA screening demonstrated that 320 the IFN-inducible genes, IFN-induced genes and IFN production were strongly 321 up-regulated in the DF patients compared with the DHF patients, suggesting a 322 significant role of IFN system during DF strain infection compared with DHF strain 323 infection [34]. Thus, it is reasonable to assume that the DHF strain might have an ability 324 to negatively regulate $\mathrm{T}$ cell responses. A recent report demonstrating that the sequence 325 of the DHF strain differed from that of DF strain in six unique amino acid residues 326 located in the membrane, envelope and non-structural genes [33], which supports our 327 notion.

Alternatively, the other possibility is that the strength of $\mathrm{T}$ cell responses might depend on the viral loads. In fact, in our results the greater T cell responses in the DF strain-infected monkeys were paralleled with higher viral loads, which was in contrast with the result of the DHF strain-infected animals with lower viral loads. Of note, the ten-fold more challenge dose of the DF strain used in this study $\left(1.9 \times 10^{5} \mathrm{PFU}\right)$ than that of the DHF strain $\left(1.8 \times 10^{4} \mathrm{PFU}\right)$ could have simply led to ten-fold more peak viral

334 RNA levels in the DF strain-infected monkeys. In either case, the relationship between 335 the strength of antiviral immune responses and the viral strains remains to be elucidated. 336 Further in vivo characterization of the antiviral immunity and the viral replication 337 kinetics induced by infection of various DENV strains isolated from DF and DHF 338 patients will help understand the mechanism of differential disease progression in the course of DENV infection.

We observed that dengue vRNA was not detected in plasma samples from marmosets re-infected with the same DENV-2 DHF strain at 33 weeks as the primary

342 infection. This result suggests that memory B cells induced in the primary DENV 343 infection were predominantly activated to produce neutralizing antibodies against the 344 same DHF strain in the secondary infection in the absence of apparent cellular immune 345 responses. A previous report showed that DENV infection induces a high-titered 346 neutralizing antibody that can provide long-term immunity to the homologous DENV 347 serotype [22], which is consistent with our result. By contrast, the role of cellular 348 immune responses in the control of DENV infection remains to be elucidated. Our 349 results in this study may suggest that cellular immune responses and neutralizing 350 antibodies cooperatively acted to control primary DENV infection. In DENV-infected 
351 patients, it may be difficult to distinguish whether each case is primary or secondary 352 DENV infection and also to serially collect blood samples for the immunological study 353 in the course of the infection, which is likely the reason for the discrepancy regarding 354 the importance of cellular immunity in DENV infection. In this point of view, our 355 marmoset model of DENV infection will further provide important information 356 regarding the roles of cellular immune responses in DENV infection. 


\section{Acknowledgements}

358 We would like to give special thanks to members of The Corporation for Production

359 and Research of Laboratory Primates for technical assistance. We also appreciate to Ms.

360 Tomoko Ikoma and Mizuho Fujita for technical assistance. This work was supported by

361 grants from the Ministry of Health, Labor and Welfare of Japan, and by the

362 Environment Research and Technology Development Fund (D-1007) from the Ministry

363 of the Environment of Japan.

364 


\section{$364 \quad$ Figure legends}

365 Fig.1 Flow cytometric analysis of naïve, central/effector memory $\mathbf{T}$ cells and

366 NK/NKT cells in marmosets. (a) Gating strategy to indentify the CD4 and CD8 T, NK and NKT cells. The G1 population was selected and analyzed for CD4 and CD8 T, NK and NKT cells. (a) Profiling of naïve, central memory, and effector memory CD4 and CD8 T cells in total CD4 and CD8 T cells. (b) Profiling of NK and NKT cells in total lymphocytes. Results shown are representative of 3 healthy marmosets used in this study.

Fig. 2 Profiling of CD4 and CD8 T, NK and NKT cells in marmosets with primary infection of DENV-2 Mal/77/08 strain. At the primary DENV infection, two marmosets were inoculated subcutaneously in the back with $1.9 \times 10^{5} \mathrm{PFU}$ of the DENV-2 Mal/77/08 strain. (a) Profiling of naïve, central memory, and effector memory CD4 and CD8 T cells in total CD4 and CD8 T cells. (b) Profiling of NK and NKT cells in total lymphocytes. (a-b) Cj08-007.

Fig. 3 Frequency of CD4 and CD8 T, NK and NKT cells in marmosets with primary infection of DENV-2 Mal/77/08 strain. At the primary DENV infection, two marmosets were inoculated subcutaneously in the back with $1.9 \times 10^{5} \mathrm{PFU}$ of the DENV-2 Mal/77/08 strain. (a) Ratios of naïve, central memory, and effector memory CD4 T cells in total CD4 T cells. (b) Ratios of naïve, central memory, and effector memory CD8 T cells in total CD8 T cells. (c) Ratios of NK and NKT cells in total lymphocytes. (a-c) Cj08-007, Cj07-011.

Fig. 4 Profiling of CD4 and CD8 T, NK and NKT cells in marmosets with primary infection of DENV-2 DHF0663 strain. At the primary DENV infection, two marmosets were inoculated subcutaneously in the back with $1.8 \times 10^{4} \mathrm{PFU}$ of the DENV-2 DHF0663 strain. (a) Profiling of naïve, central memory, and effector memory

392 CD4 and CD8 T cells in total CD4 and CD8 T cells. (b) Profiling of NK and NKT cells 393 in total lymphocytes. (a-b) Cj07-006. 
397 marmosets were inoculated subcutaneously in the back with $1.8 \times 10^{4}$ PFU of the

398 DENV-2 DHF0663 strain. (a) Ratios of naïve, central memory, and effector memory

399 CD4 T cells in total CD4 T cells. (b) Ratios of naïve, central memory, and effector

400 memory CD8 T cells in total CD8 T cells. (c) Ratios of NK and NKT cells in total

401 lymphocytes. (a-c) Cj07-006, Cj07-008.

402

403 Fig. 6 Profiling of CD4 and CD8 T, NK and NKT cells in marmosets with

404 re-challenging DENV-2 DHF0663 strain. In the case of the DENV re-challenge study,

405 two marmosets initially inoculated with $1.8 \times 10^{5}$ PFU of the DHF0663 strain were

406 re-inoculated 33 weeks after the primary challenge with $1.8 \times 10^{5}$ PFU of the same strain.

407 (a) Profiling of naïve, central memory, and effector memory CD4 and CD8 T cells in

408 total CD4 and CD8 T cells. (b) Profiling of NK and NKT cells in total lymphocytes.

409 (a-b) Cj07-007.

410

411 Fig. 7 Frequency of CD4 and CD8 T, NK and NKT cells in marmosets with

412 re-challenging DENV-2 DHF0663 strain. In the case of the DENV re-challenge study,

413 two marmosets initially inoculated with $1.8 \times 10^{5}$ PFU of the DHF0663 strain were

414 re-inoculated 33 weeks after the primary challenge with $1.8 \times 10^{5} \mathrm{PFU}$ of the same strain.

415 (a) Ratios of naïve, central memory, and effector memory CD4 T cells in total CD4 T

416 cells. (b) Ratios of naïve, central memory, and effector memory CD8 T cells in total

417 CD8 T cells. (c) Ratios of NK and NKT cells in total lymphocytes. (a-c) Cj07-007,

418 Cj07-014. 


\section{References}

420 1. Balsitis SJ, Williams KL, Lachica R, Flores D, Kyle JL, Mehlhop E, Johnson S, Diamond MS, Beatty PR, Harris E (2010) Lethal antibody enhancement of dengue disease in mice is prevented by Fc modification. PLoS Pathog

6:e1000790

2. Beaumier CM, Mathew A, Bashyam HS, Rothman AL (2008) Cross-reactive memory CD8(+) T cells alter the immune response to heterologous secondary dengue virus infections in mice in a sequence-specific manner. J Infect Dis 197:608-617

3. Beaumier CM, Rothman AL (2009) Cross-reactive memory CD4+ T cells alter the CD8+ T-cell response to heterologous secondary dengue virus infections in mice in a sequence-specific manner. Viral Immunol 22:215-219

4. Beaumier CM, Jaiswal S, West KY, Friberg H, Mathew A, Rothman AL (2010) Differential in vivo clearance and response to secondary heterologous infections by H2(b)-restricted dengue virus-specific CD8+ T cells. Viral Immunol 23:477-485

435 5. Fadilah SA, Sahrir S, Raymond AA, Cheong SK, Aziz JA, Sivagengei K (1999) 436 Quantitation of T lymphocyte subsets helps to distinguish dengue hemorrhagic fever from classic dengue fever during the acute febrile stage. Southeast Asian J Trop Med Public Health 30:710-717

439 6. Goncalvez AP, Engle RE, St Claire M, Purcell RH, Lai CJ (2007) Monoclonal antibody-mediated enhancement of dengue virus infection in vitro and in vivo and strategies for prevention. Proc Natl Acad Sci U S A 104:9422-9427

442 7. Green S, Pichyangkul S, Vaughn DW, Kalayanarooj S, Nimmannitya S, Nisalak

446 8. Green S, Vaughn DW, Kalayanarooj S, Nimmannitya S, Suntayakorn S, Nisalak peripheral blood lymphocytes from children with dengue hemorrhagic fever. $\mathbf{J}$

450 9. Gupta S, Gollapudi S (2008) CD95-mediated apoptosis in naive, central and effector memory subsets of CD4+ and CD8+ T cells in aged humans. Exp 
Gerontol 43:266-274

10. Guzman MG, Alvarez M, Rodriguez-Roche R, Bernardo L, Montes T, Vazquez S, Morier L, Alvarez A, Gould EA, Kouri G, Halstead SB (2007) Neutralizing antibodies after infection with dengue 1 virus. Emerg Infect Dis 13:282-286

11. Halstead SB (1979) In vivo enhancement of dengue virus infection in rhesus monkeys by passively transferred antibody. J Infect Dis 140:527-533

12. Halstead SB (2007) Dengue. Lancet 370:1644-1652

13. Henchal EA, Henchal LS, Schlesinger JJ (1988) Synergistic interactions of anti-NS1 monoclonal antibodies protect passively immunized mice from lethal challenge with dengue 2 virus. J Gen Virol 69 ( Pt 8):2101-2107

14. Hus I, Staroslawska E, Bojarska-Junak A, Dobrzynska-Rutkowska A, Surdacka A, Wdowiak P, Wasiak M, Kusz M, Twardosz A, Dmoszynska A, Rolinski J (2011) CD3+/CD16+CD56+ cell numbers in peripheral blood are correlated with higher tumor burden in patients with diffuse large B-cell lymphoma. Folia Histochem Cytobiol 49:183-187

15. Kaufman BM, Summers PL, Dubois DR, Eckels KH (1987) Monoclonal antibodies against dengue 2 virus E-glycoprotein protect mice against lethal dengue infection. Am J Trop Med Hyg 36:427-434

16. Kaufman BM, Summers PL, Dubois DR, Cohen WH, Gentry MK, Timchak RL, Burke DS, Eckels KH (1989) Monoclonal antibodies for dengue virus prM glycoprotein protect mice against lethal dengue infection. Am J Trop Med Hyg 41:576-580

17. Khvedelidze M, Chkhartishvili N, Abashidze L, Dzigua L, Tsertsvadze T (2008) Expansion of CD3/CD16/CD56 positive NKT cells in HIV/AIDS: the pilot study. Georgian Med News:78-83

18. Kyle JL, Balsitis SJ, Zhang L, Beatty PR, Harris E (2008) Antibodies play a greater role than immune cells in heterologous protection against secondary dengue virus infection in a mouse model. Virology 380:296-303

19. Mathew A, Rothman AL (2008) Understanding the contribution of cellular immunity to dengue disease pathogenesis. Immunol Rev 225:300-313

20. Mladinich KM, Piaskowski SM, Rudersdorf R, Eernisse CM, Weisgrau KL, Martins MA, Furlott JR, Partidos CD, Brewoo JN, Osorio JE, Wilson NA, Rakasz EG, Watkins DI (2012) Dengue virus-specific CD4+ and CD8+ T 
485

486

487

488

489

490

491

492

493

494

495

496

497

498

499

500

501

502

503

504

505

506

507

508

509

510

511

512

513

514

515

516

517

lymphocytes target NS1, NS3 and NS5 in infected Indian rhesus macaques.

Immunogenetics 64:111-121

21. Mueller YM, Makar V, Bojczuk PM, Witek J, Katsikis PD (2003) IL-15

enhances the function and inhibits CD95/Fas-induced apoptosis of human CD4+ and CD8+ effector-memory T cells. Int Immunol 15:49-58

22. Murphy BR, Whitehead SS (2011) Immune response to dengue virus and prospects for a vaccine. Annu Rev Immunol 29:587-619

23. Myint KS, Endy TP, Mongkolsirichaikul D, Manomuth C, Kalayanarooj S, Vaughn DW, Nisalak A, Green S, Rothman AL, Ennis FA, Libraty DH (2006) Cellular immune activation in children with acute dengue virus infections is modulated by apoptosis. J Infect Dis 194:600-607

24. Omatsu T, Moi ML, Hirayama T, Takasaki T, Nakamura S, Tajima S, Ito M, Yoshida T, Saito A, Katakai Y, Akari H, Kurane I (2011) Common marmoset (Callithrix jacchus) as a primate model of dengue virus infection: development of high levels of viremia and demonstration of protective immunity. J Gen Virol 92:2272-2280

25. Omatsu T, Moi ML, Takasaki T, Nakamura S, Katakai Y, Tajima S, Ito M, Yoshida T, Saito A, Akari H, Kurane I (2012) Changes in hematological and serum biochemical parameters in common marmosets (Cllithrix jacchus) after inoculation with dengue virus. J Med Primatol doi:10.1111/j.1600-9684.2012.00552.x

26. Onlamoon N, Noisakran S, Hsiao HM, Duncan A, Villinger F, Ansari AA, Perng GC (2010) Dengue virus-induced hemorrhage in a nonhuman primate model. Blood 115:1823-1834

27. Pawitan JA (2011) Dengue virus infection: predictors for severe dengue. Acta Med Indones 43:129-135

28. Pitcher CJ, Hagen SI, Walker JM, Lum R, Mitchell BL, Maino VC, Axthelm MK, Picker LJ (2002) Development and homeostasis of T cell memory in rhesus macaque. J Immunol 168:29-43

29. Rigau-Perez JG, Clark GG, Gubler DJ, Reiter P, Sanders EJ, Vorndam AV (1998) Dengue and dengue haemorrhagic fever. Lancet 352:971-977

30. Sabin AB (1950) The dengue group of viruses and its family relationships. Bacteriol Rev 14:225-232 
518 31. Sierra B, Garcia G, Perez AB, Morier L, Rodriguez R, Alvarez M, Guzman MG

519

520

521

522

523

524

525

526

527

528

529

530

531

532

533

534

535

536

537

538

539

540

541

542

543

544

545

546

547

548

549

550 (2002) Long-term memory cellular immune response to dengue virus after a natural primary infection. Int J Infect Dis 6:125-128

32. Terabe M, Berzofsky JA (2008) The role of NKT cells in tumor immunity. Adv Cancer Res 101:277-348

33. Tuiskunen A, Monteil V, Plumet S, Boubis L, Wahlstrom M, Duong V, Buchy P, Lundkvist A, Tolou H, Leparc-Goffart I (2011) Phenotypic and genotypic characterization of dengue virus isolates differentiates dengue fever and dengue hemorrhagic fever from dengue shock syndrome. Arch Virol 156:2023-2032

34. Ubol S, Masrinoul P, Chaijaruwanich J, Kalayanarooj S, Charoensirisuthikul T, Kasisith J (2008) Differences in global gene expression in peripheral blood mononuclear cells indicate a significant role of the innate responses in progression of dengue fever but not dengue hemorrhagic fever. J Infect Dis 197:1459-1467

35. Yauch LE, Zellweger RM, Kotturi MF, Qutubuddin A, Sidney J, Peters B, Prestwood TR, Sette A, Shresta S (2009) A protective role for dengue virus-specific CD8+ T cells. J Immunol 182:4865-4873

36. Yauch LE, Prestwood TR, May MM, Morar MM, Zellweger RM, Peters B, Sette A, Shresta S (2010) CD4+ T cells are not required for the induction of dengue virus-specific CD8+ $\mathrm{T}$ cell or antibody responses but contribute to protection after vaccination. J Immunol 185:5405-5416

37. Yoshida T, Saito A, Iwasaki Y, Iijima S, Kurosawa T, Katakai Y, Yasutomi Y, Reimann KA, Hayakawa T, Akari H (2010) Characterization of natural killer cells in tamarins: a technical basis for studies of innate immunity. Front Microbiol 1:128

38. Yoshida T, Omatsu T, Saito A, Katakai Y, Iwasaki Y, Iijima S, Kurosawa T, Hamano M, Nakamura S, Takasaki T, Yasutomi Y, Kurane I, Akari H (2012) $\mathrm{CD16(+)}$ natural killer cells play a limited role against primary dengue virus infection in tamarins. Arch Virol 157:363-368

39. Zompi S, Santich BH, Beatty PR, Harris E (2012) Protection from secondary dengue virus infection in a mouse model reveals the role of serotype cross-reactive B and T cells. J Immunol 188:404-416 
551

552 


\section{Conflict of Interest Statement:}

553 The authors declare that the research was conducted in the absence of any commercial 554 or financial relationships that could be construed as a potential conflict of interest. 555 


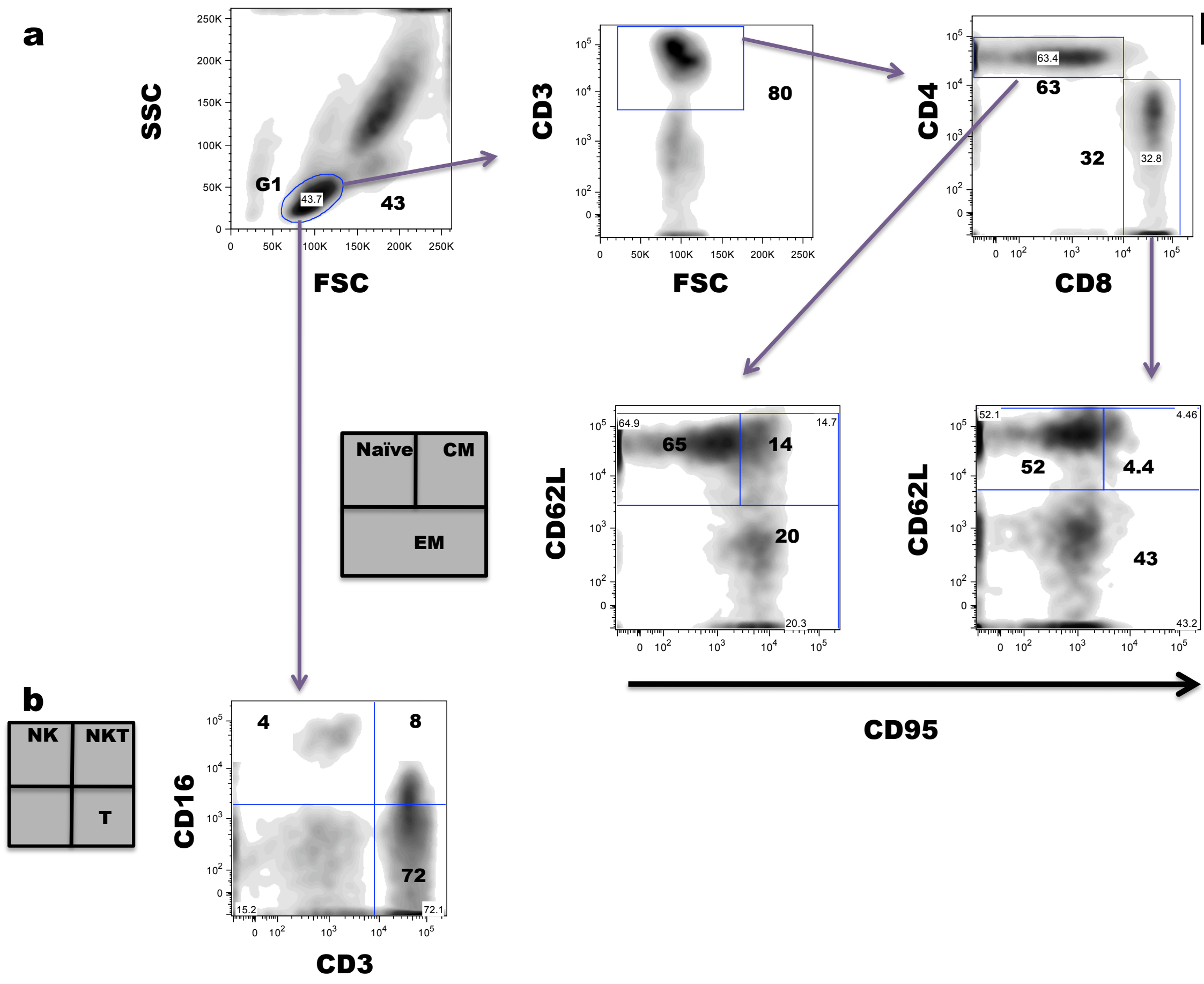

Fig. 1 


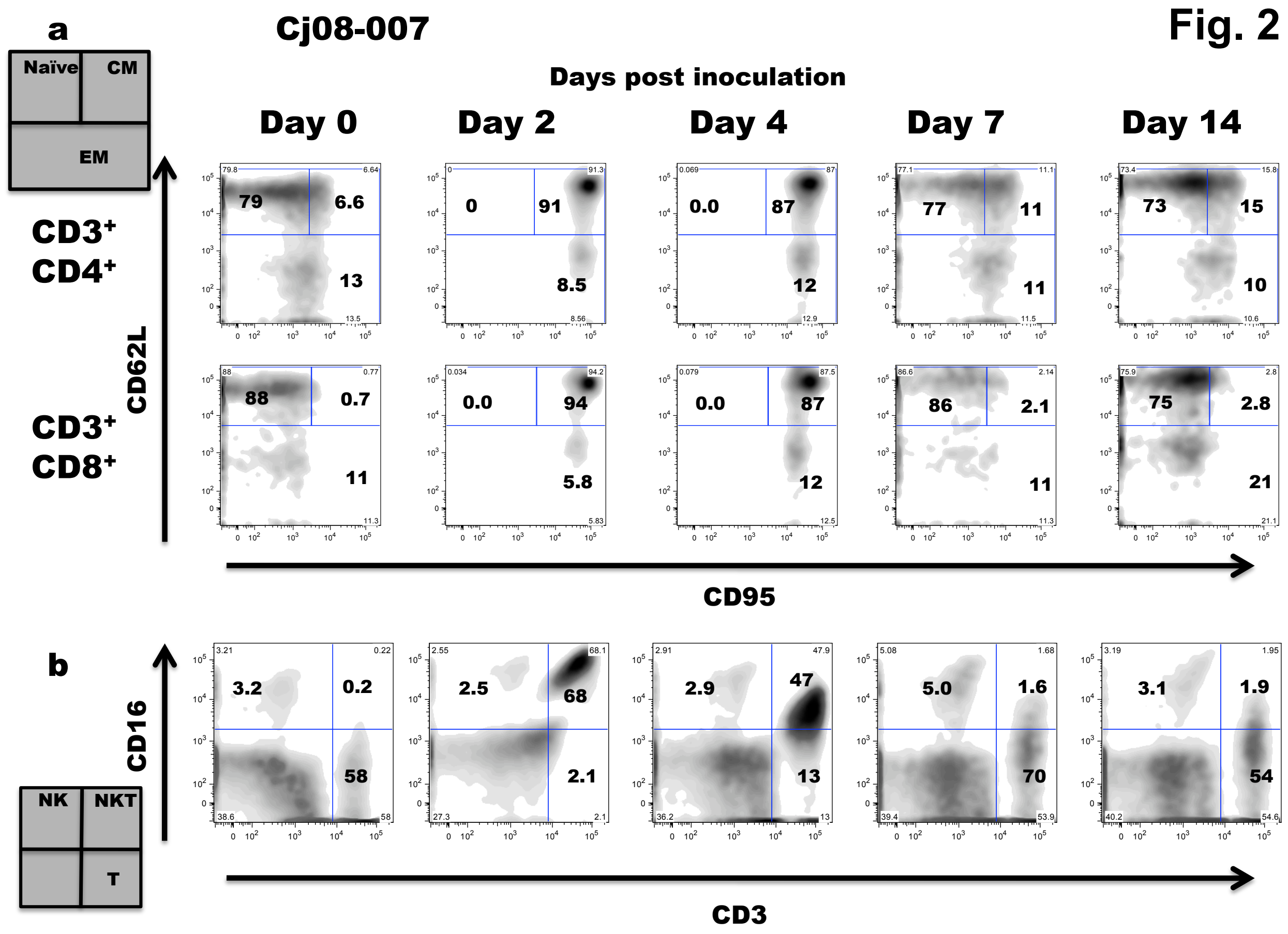


a

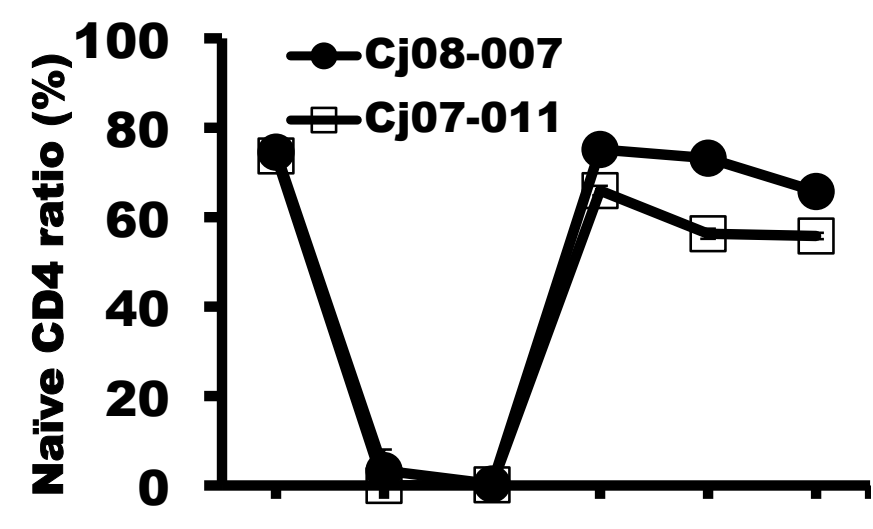

b

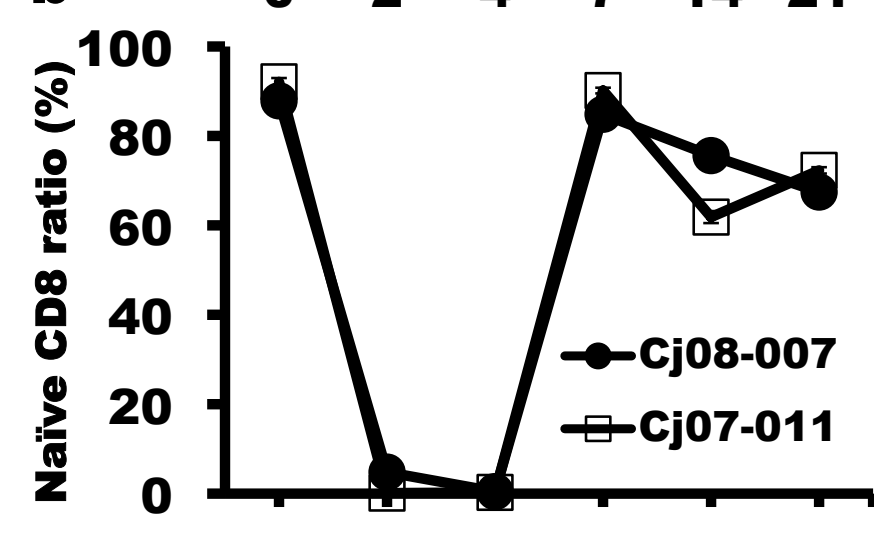

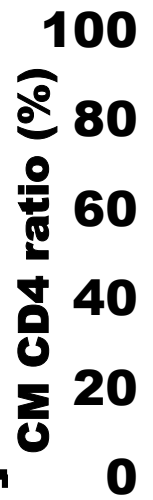
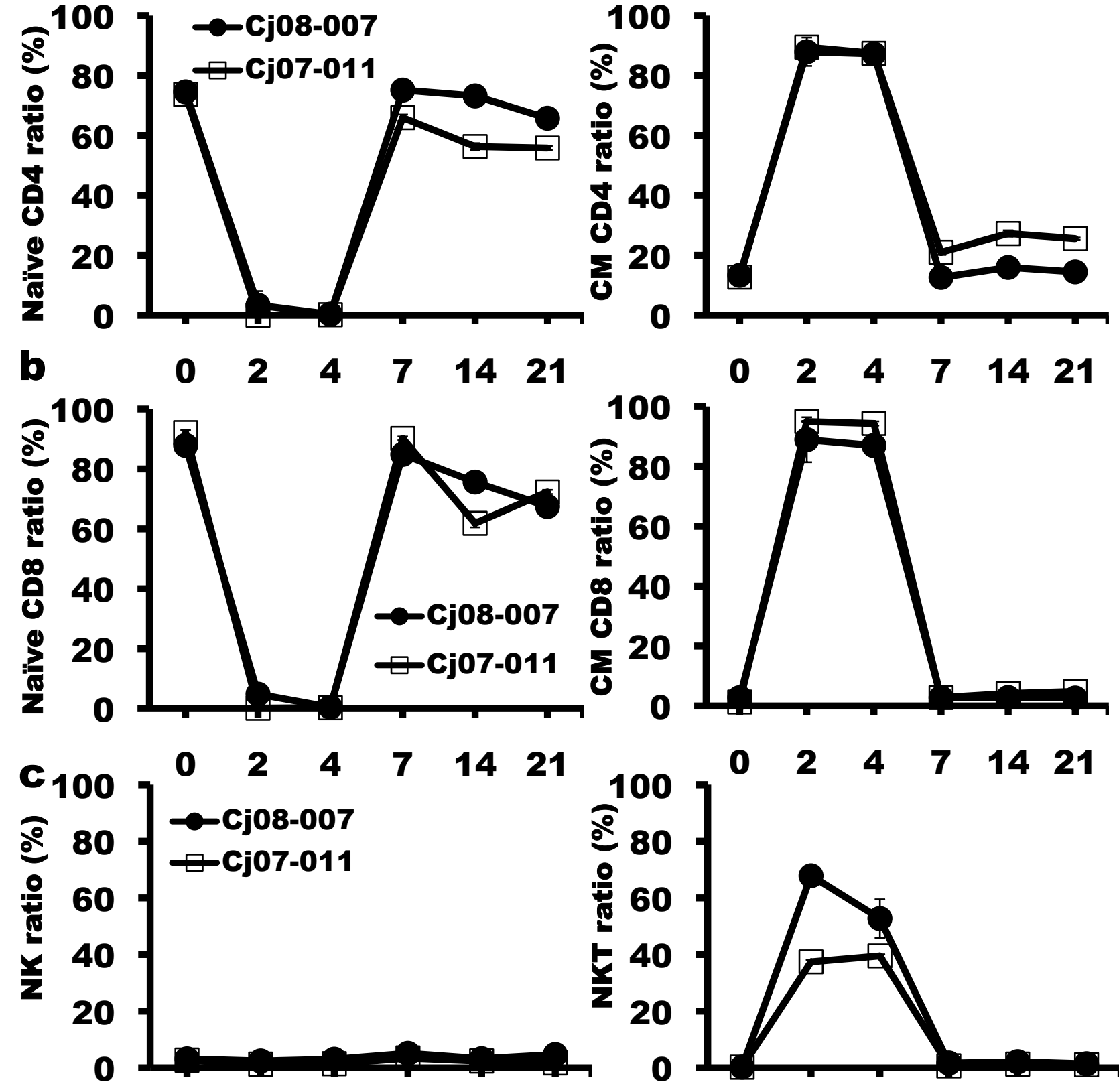

$\begin{array}{llllll}0 & 2 & 4 & 7 & 14 & 21\end{array}$ Days post inoculation

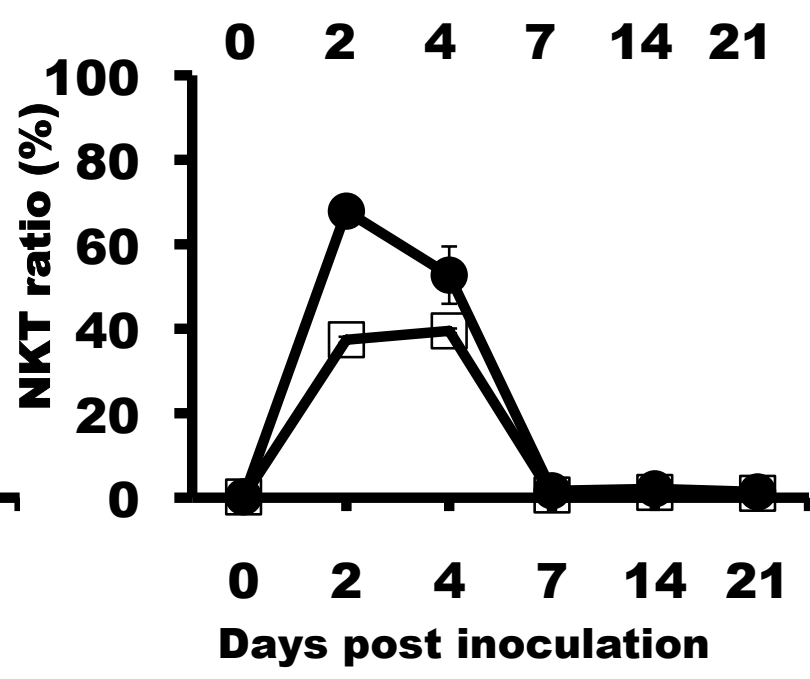

Fig. 3
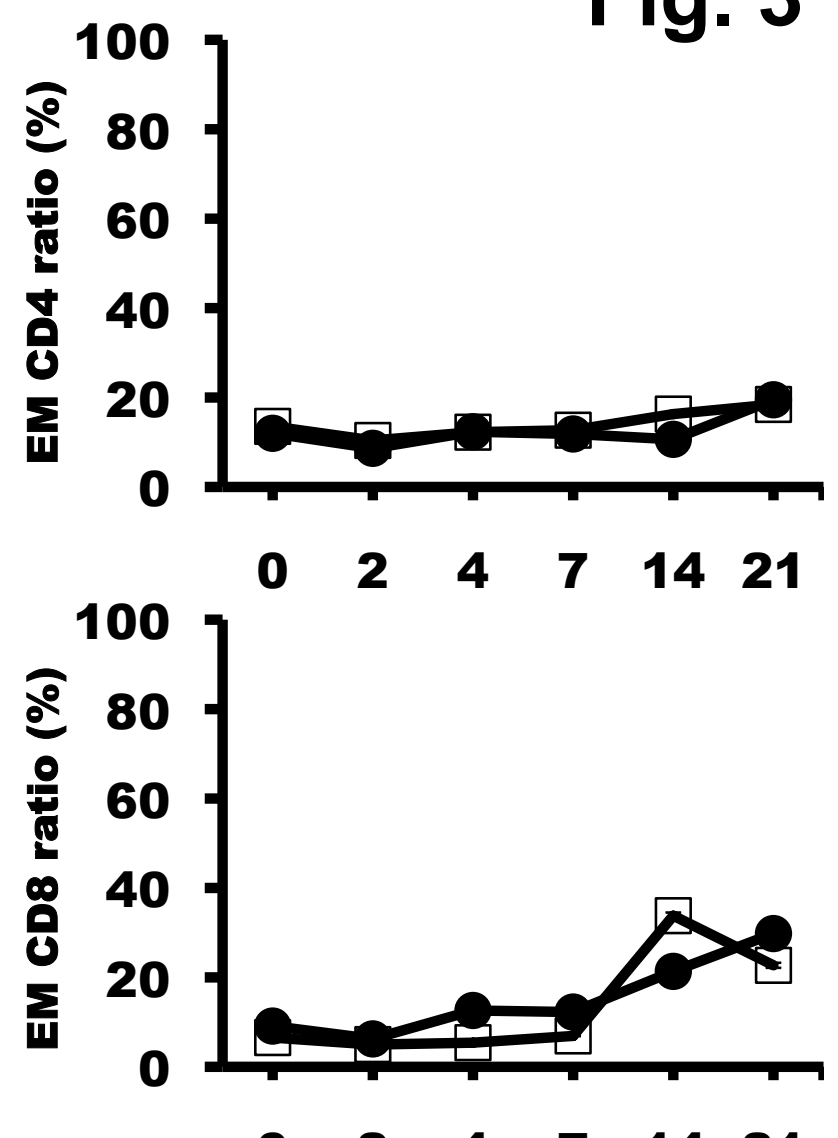

$\begin{array}{llllll}0 & 2 & 4 & 7 & 14 & 21\end{array}$

Days post inoculation 
Cj07-006

Fig. 4

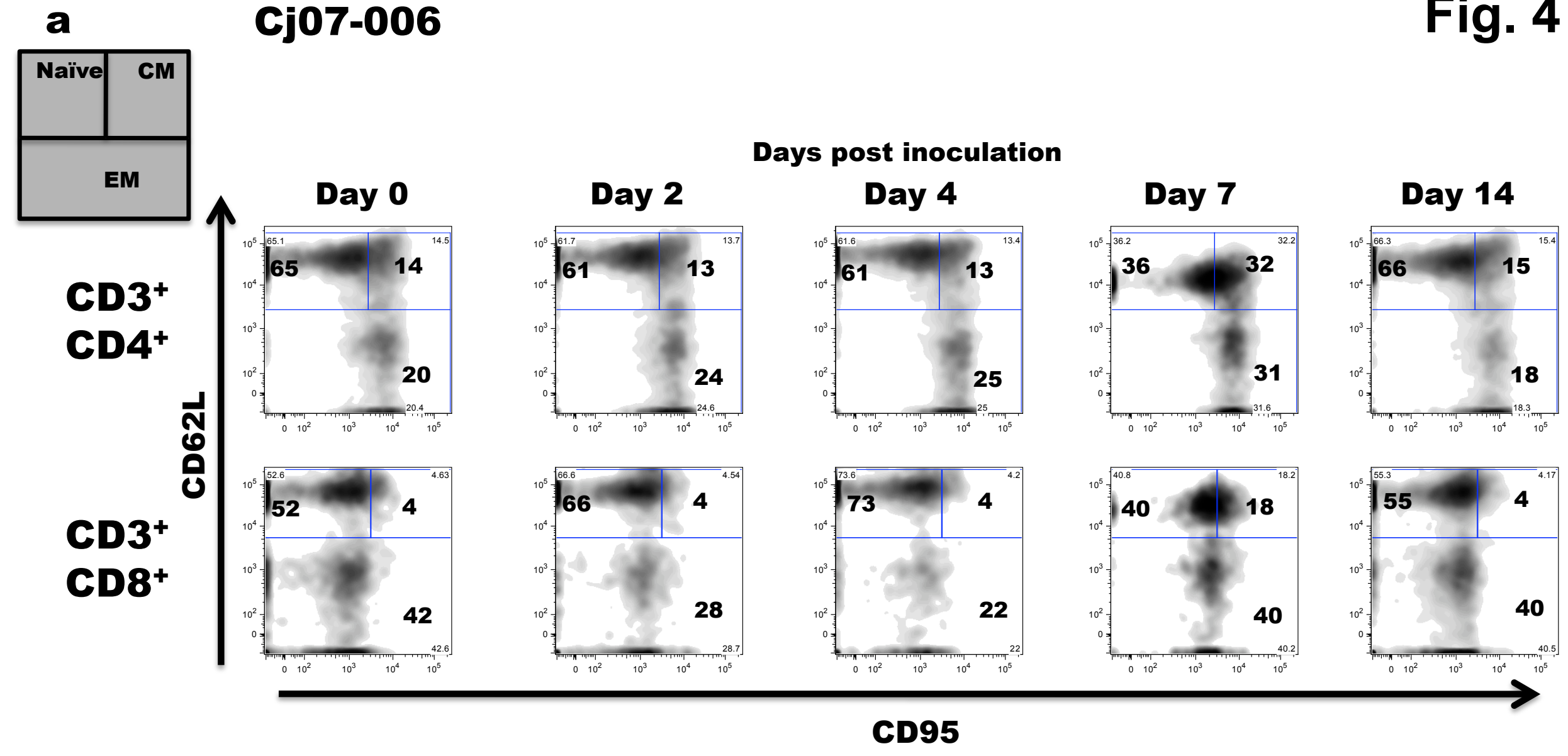

b
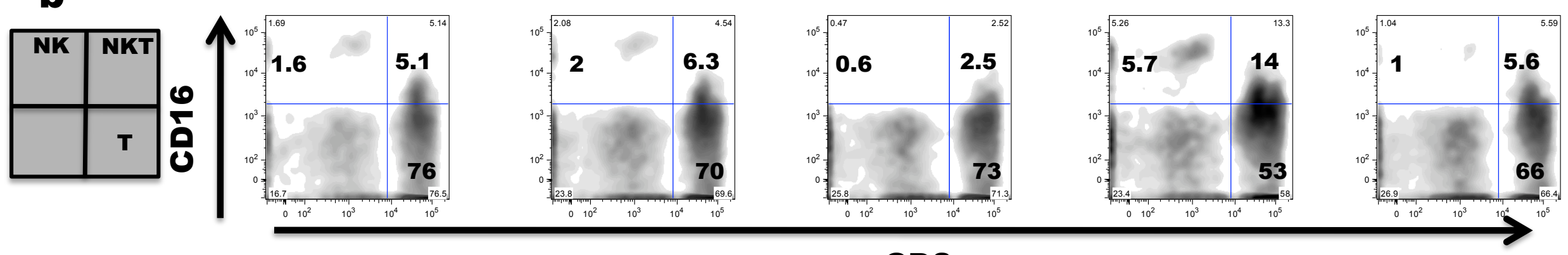

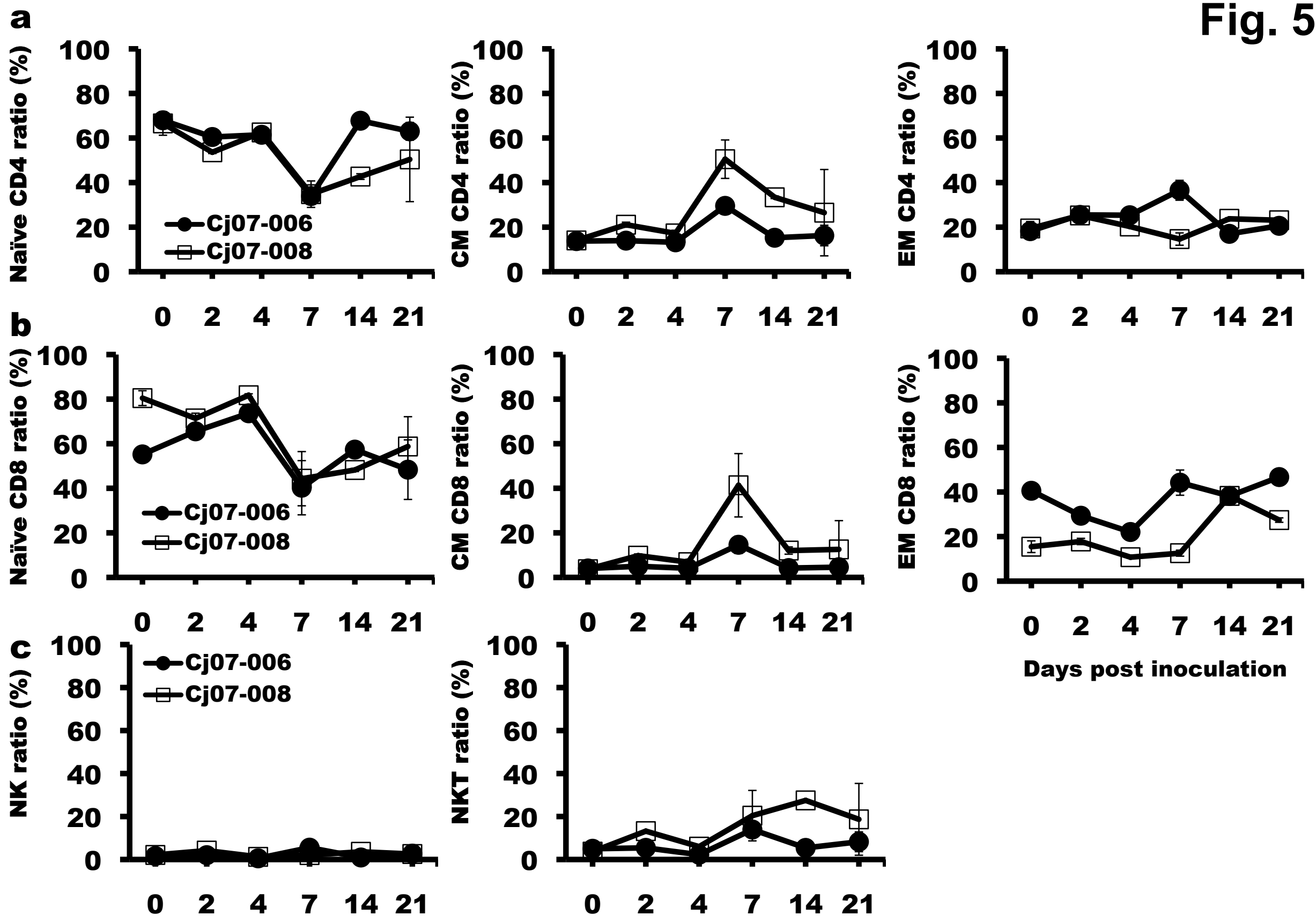

Days post inoculation

Days post inoculation 
a Cj07-007

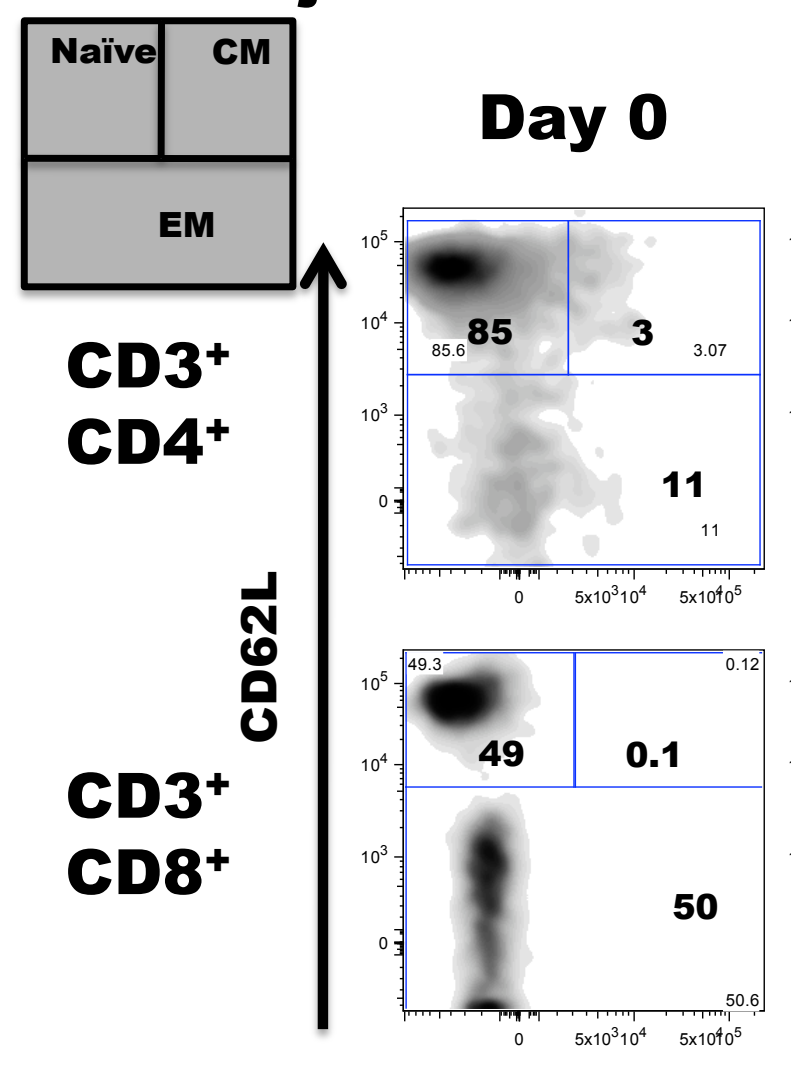

Days post inoculation

Day 2
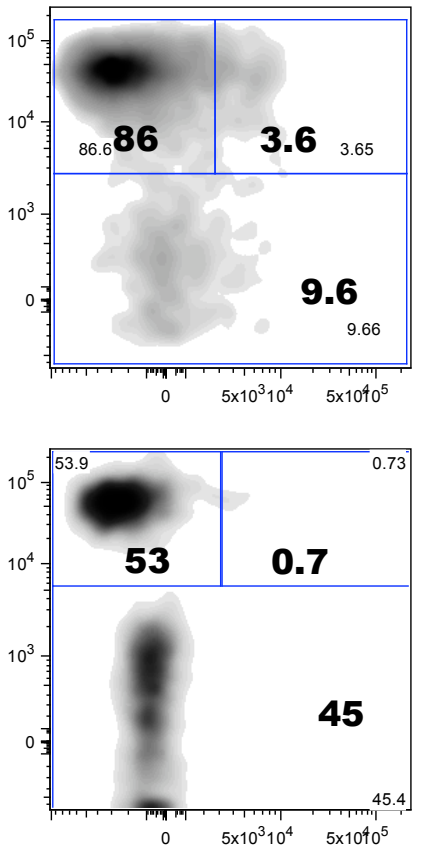

Day 4
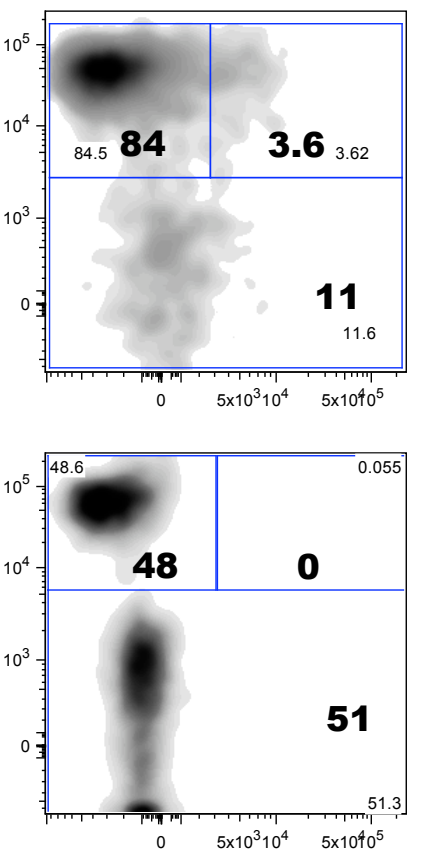

Day 7
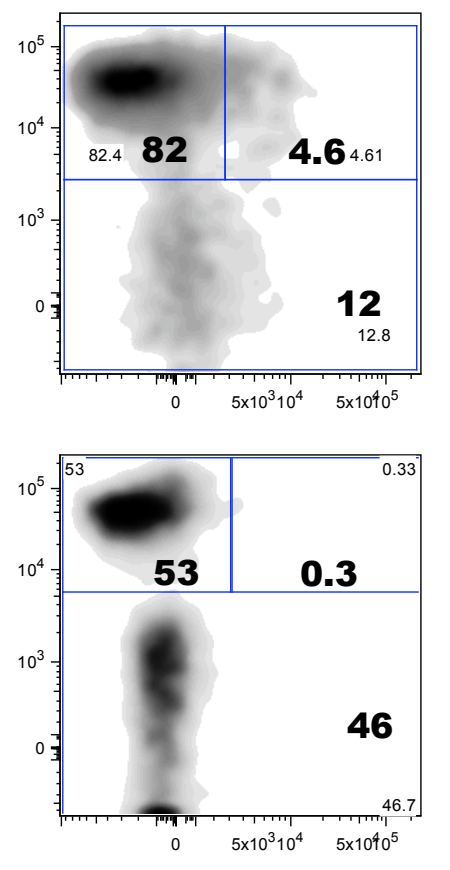

Fig. 6

\section{Day 14}
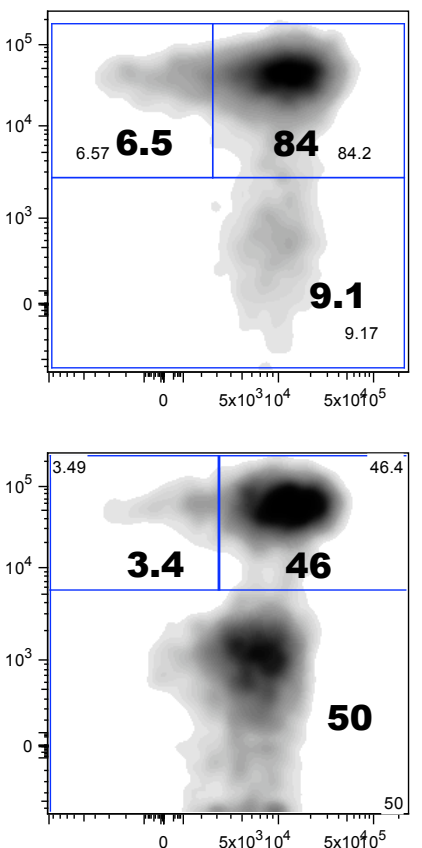

\section{CD95}

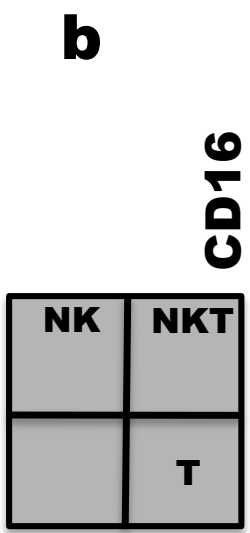

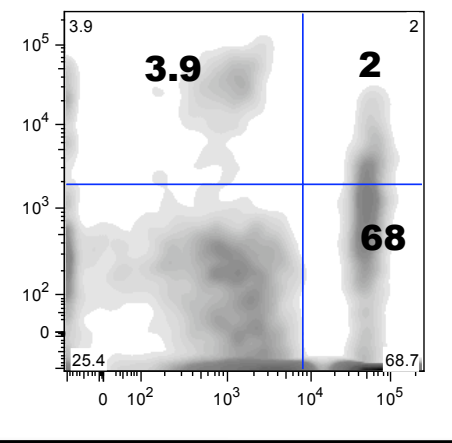

CD3
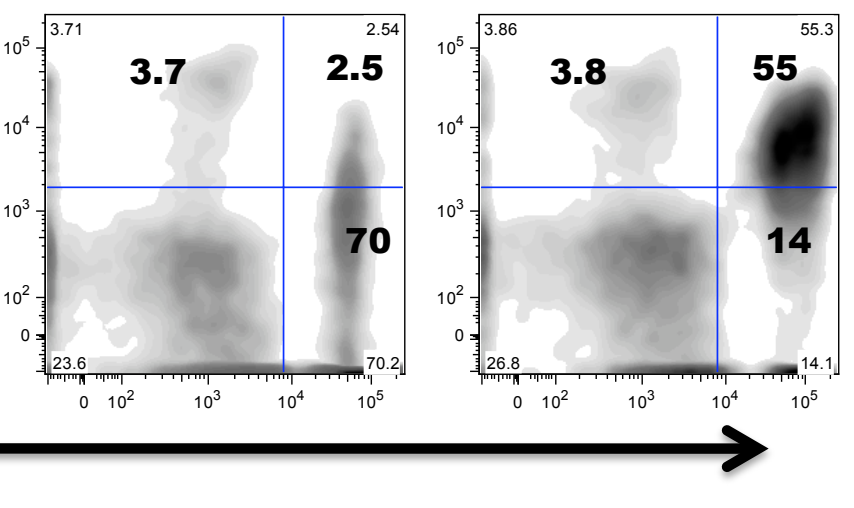

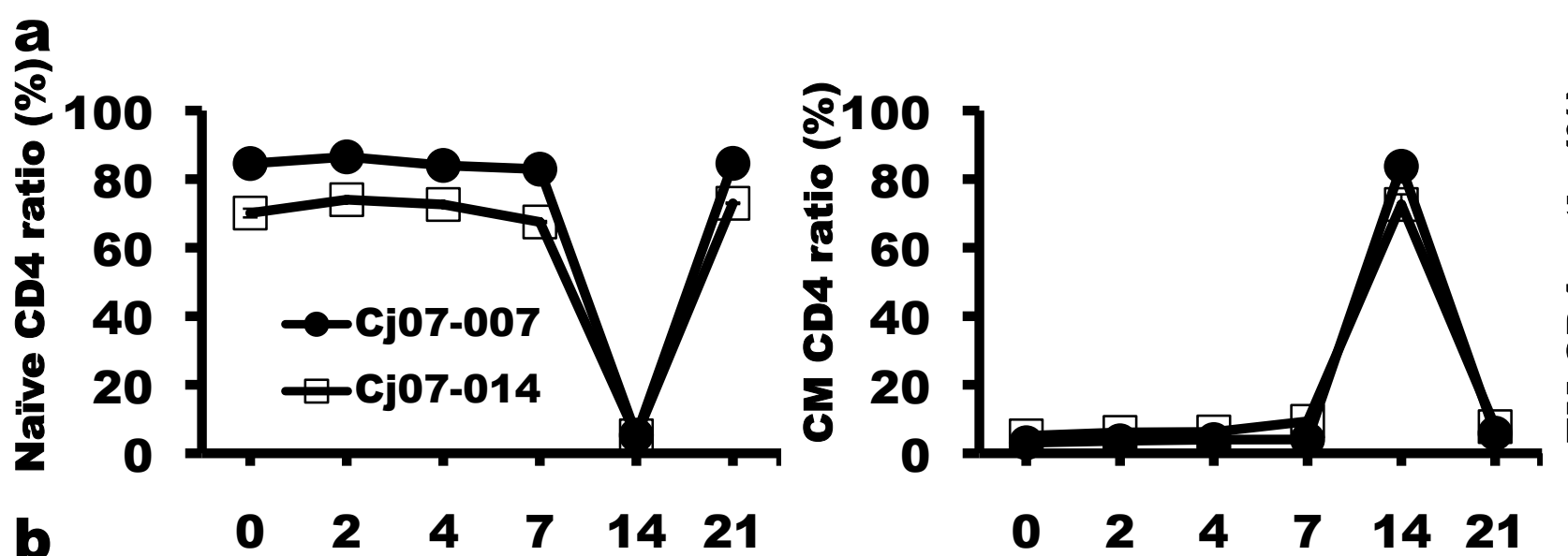

Fig. 7
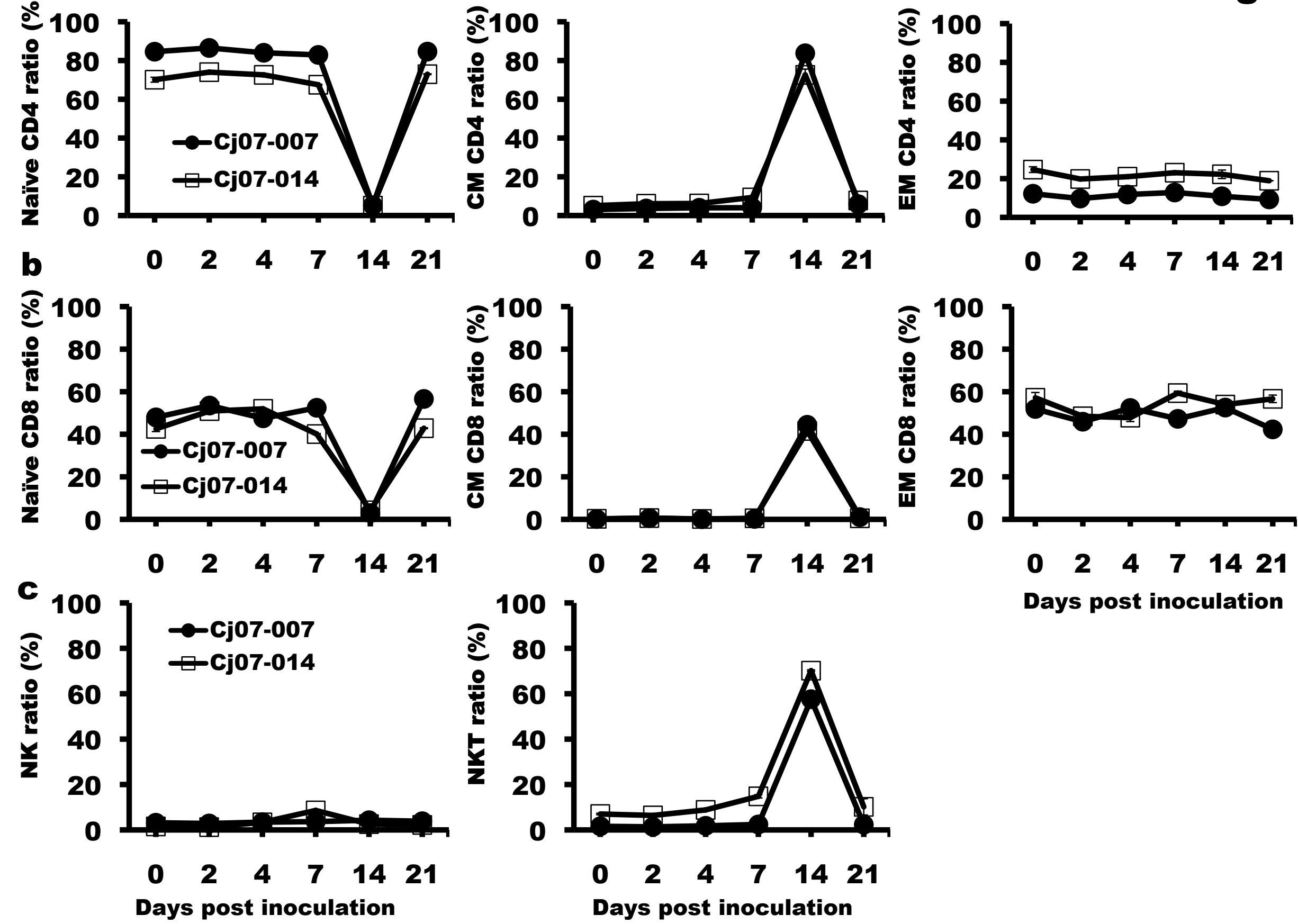

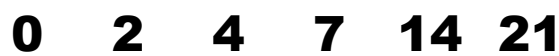

Days post inoculation
Days post inoculation 
Table 1. Subpopulation ratios of lymphocytes in marmosets.

\begin{tabular}{|c|c|}
\hline Subpopulation name & $\begin{array}{c}\text { Subpopulation Ratios } \\
\text { (Mean士SD: \%) }\end{array}$ \\
\hline CD3 $^{+}$ & $75.7 \pm 6.4$ \\
\hline $\mathrm{CD}^{+}{ }^{+} \mathrm{CD}^{+}+$ & $65.4 \pm 6.8$ \\
\hline 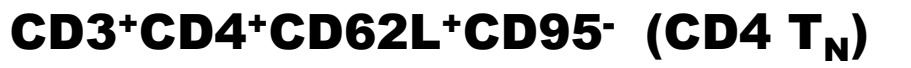 & $65.9 \pm 3.7$ \\
\hline $\mathrm{CD3}^{+}{ }^{+} \mathrm{CD} 4+{ }^{+} \mathrm{CD} 62 L^{+}{ }^{2} \mathrm{CD} 95^{+}\left(\mathrm{CD} 4 \mathrm{~T}_{\mathrm{CM}}\right)$ & $16.4 \pm 2.9$ \\
\hline $\mathrm{CD3}^{+}{ }^{-C D 4}{ }^{+}$CD62L-CD95 ${ }^{\prime}$ (CD4 T & $19.5 \pm 2.5$ \\
\hline CD3 $^{+}$CD8 $^{+}$ & $29.0 \pm 8.0$ \\
\hline $\mathrm{CD3}^{+}{ }^{+}{ }^{2}{ }^{+}{ }^{-C D 62 L+C D 95-}\left(\mathrm{CD8} \mathrm{T}_{\mathrm{N}}\right)$ & $66.7 \pm 10.2$ \\
\hline 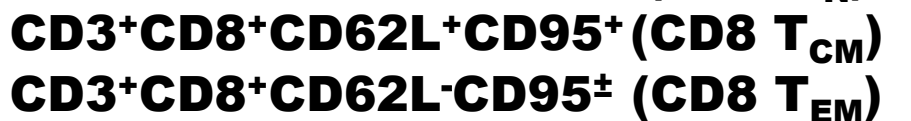 & $\begin{array}{c}4.7 \pm 3.6 \\
28.8 \pm 14.8\end{array}$ \\
\hline $\begin{array}{lc}\text { CD3 }^{-C D 16}{ }^{+} & \text {(NK) } \\
\text { CD3 }^{+} \text {CD16 }^{+} & \text {(NKT) }\end{array}$ & $\begin{array}{l}4.2 \pm 2.6 \\
5.1 \pm 3.4\end{array}$ \\
\hline
\end{tabular}

SD: Standard deviation.

Results shown are mean士SD from 3 healthy marmosets. 
Table 2. Subpopulation ratios of lymphocytes in marmosets during primary DENV infection (Mal/77/08).

Subpopulation name

\begin{tabular}{|c|c|c|c|c|c|c|c|}
\hline & & \multicolumn{6}{|c|}{ Days after inoculation } \\
\hline & & Day 0 & Day 2 & Day 4 & Day 7 & Day 14 & Day 21 \\
\hline CD3+CD4+CD62L+CD95- & $\left(C D 4 T_{N}\right)$ & $74.1 \pm 0.9$ & $1.6 \pm 3.3$ & $0.2 \pm 0.3$ & $70.5 \pm 5.5$ & $64.8 \pm 9.7$ & $60.8 \pm 5.9$ \\
\hline $\mathrm{CD3}^{+}{ }^{+} \mathrm{CD4}{ }^{+} \mathrm{CD} 62 \mathrm{~L}^{+} \mathrm{CD}^{+}{ }^{+}$ & $\left(\right.$CD4 $\left.T_{\mathrm{CM}}\right)$ & $13 \pm 0.4$ & $88.7 \pm 2.8$ & $87.4 \pm 0.2$ & $16.8 \pm 5.0$ & $21.6 \pm 6.5$ & $20 \pm 6.4$ \\
\hline $\mathrm{CD3}^{+} \mathrm{CD} 4{ }^{+} \mathrm{CD} 62 \mathrm{~L}-\mathrm{CD}^{ \pm} 5^{ \pm}$ & $\left(C D 4 T_{E M}\right)$ & $12.8 \pm 0.9$ & $9.5 \pm 1.0$ & $12.3 \pm 0.4$ & $12.3 \pm 0.5$ & $13.4 \pm 3.2$ & $18.9 \pm 1.4$ \\
\hline CD3+CD8+CD62L+CD95- & $\left(C D 8 T_{N}\right)$ & $89.9 \pm 2.5$ & $2.5 \pm 4.7$ & $0.3 \pm 0.3$ & $87.5 \pm 3.3$ & $68.7 \pm 7.9$ & $69.8 \pm 3.1$ \\
\hline $\mathrm{CD3}^{+} \mathrm{CD8}^{+}{ }^{\mathrm{CD}} 62 \mathrm{~L}^{+}{ }^{+} \mathrm{CD} 5^{+}$ & $\left(\right.$CD8 $\left.T_{\mathrm{CM}}\right)$ & $2.1 \pm 0.8$ & $91.9 \pm 5.5$ & $90.6 \pm 4.2$ & $2.8 \pm 0.5$ & $3.5 \pm 0.8$ & $3.8 \pm 1.2$ \\
\hline $\mathrm{CD3}^{+}{ }^{\mathrm{CD} 8}{ }^{+}{ }^{-C D 62 L-C D 95}{ }^{ \pm}$ & $\left(C D 8 T_{E M}\right)$ & $7.8 \pm 1.6$ & $5.6 \pm 0.8$ & $9.0 \pm 4.1$ & $9.5 \pm 3.1$ & $27.6 \pm 7.2$ & $26.3 \pm 4.3$ \\
\hline CD3-CD16 ${ }^{+}$ & (NK) & $2.9 \pm 0.2$ & $1.8 \pm 0.6$ & $2.2 \pm 0.9$ & $4.2 \pm 0.9$ & $2.8 \pm 0.4$ & $3.2 \pm 1.7$ \\
\hline $\mathrm{CD}^{+}{ }^{+} \mathrm{CD} 16^{+}$ & (NKT) & $0.2 \pm 0.0$ & $52.6 \pm 17$ & $46.1 \pm 8.5$ & $1.1 \pm 0.5$ & $1.7 \pm 0.5$ & $1.2 \pm 0.2$ \\
\hline
\end{tabular}

SD: Standard deviation.

Subpopulation Ratios (Mean士SD: \%)

\section{Days after inoculation}

Results shown are mean士SD from 2 marmosets as shown in Figure 3. 
Table 3. Subpopulation ratios of lymphocytes in marmosets during primary DENV infection (DHF0663).

Subpopulation name

Subpopulation Ratios

(Mean士SD: \%)

Days after inoculation

\begin{tabular}{llllll}
\hline Day 0 & Day 2 & Day 4 & Day 7 & Day 14 & Day 21 \\
\hline
\end{tabular}

\begin{tabular}{|c|c|c|c|c|c|c|c|}
\hline $\mathrm{CD3}^{+}{ }^{+}{ }^{-} 4^{+}{ }^{-C D 62 L}+{ }^{+}$ & $\left(C D 4 T_{N}\right)$ & $67.3 \pm 3.6$ & $57.0 \pm 4.0$ & $61.9 \pm 0.9$ & $34.4 \pm 3.6$ & $55.2 \pm 14$ & $56.7 \pm 13$ \\
\hline $\mathrm{CD3}^{+}{ }^{+} \mathrm{CD} 4+{ }^{+} \mathrm{CD} 62 \mathrm{~L}^{+}{ }^{+} \mathrm{CD} 5^{+}$ & $\left(\mathrm{CD} 4 \mathrm{~T}_{\mathrm{CM}}\right)$ & $13.9 \pm 1.3$ & $17.5 \pm 4.1$ & $15.2 \pm 2.5$ & $40.0 \pm 13$ & $33.8 \pm 10$ & $21.3 \pm 12$ \\
\hline $\mathrm{CD}^{+}{ }^{+} \mathrm{CD} 4^{+} \mathrm{CD} 62 \mathrm{~L}-\mathrm{CD}^{2} 5^{ \pm}$ & $\left(C D 4 T_{E M}\right)$ & $18.8 \pm 2.2$ & $25.3 \pm 0.9$ & $22.8 \pm 2.9$ & $25.6 \pm 13$ & $20.3 \pm 4.0$ & $21.8 \pm 1.5$ \\
\hline $\mathrm{CD3}^{+} \mathrm{CD}{ }^{+}+\mathrm{CD} 62 \mathrm{~L}+\mathrm{CD} 95-$ & $\left(C D 8 T_{N}\right)$ & $67.8 \pm 14$ & $68.4 \pm 3.7$ & $77.7 \pm 4.6$ & $42.2 \pm 7.4$ & $52.7 \pm 5.5$ & $53.5 \pm 9.8$ \\
\hline $\mathrm{CD3}^{+}{ }^{+} \mathrm{CD} 8^{+}{ }^{-C D 62 L}+{ }^{+} \mathrm{CD} 95^{+}$ & $\left(\right.$CD8 $\left.T_{C M}\right)$ & $3.9 \pm 0.6$ & $7.4 \pm 2.8$ & $5.5 \pm 1.6$ & $28 \pm 17$ & $8.1 \pm 4.6$ & $8.6 \pm 8.9$ \\
\hline $\mathrm{CD3}^{+} \mathrm{CD8}^{+} \mathrm{CD} 62 \mathrm{~L}-\mathrm{CD}^{-} 5^{ \pm}$ & $\left(\right.$CD8 $\left.T_{E M}\right)$ & $28 \pm 14$ & $23.5 \pm 6.7$ & $16.4 \pm 6.5$ & $28.3 \pm 18$ & $38.2 \pm 1.9$ & $37.0 \pm 11$ \\
\hline CD3-CD16 $^{+}$ & (NK) & $4.7 \pm 1.0$ & $4.2 \pm 1.9$ & $2.0 \pm 1.1$ & $6.3 \pm 2.3$ & $5.1 \pm 2.2$ & $7.3 \pm 1.2$ \\
\hline $\mathrm{CD3}^{+} \mathrm{CD}^{\mathrm{C}}{ }^{+}$ & (NKT) & $7.8 \pm 1.0$ & $9.3 \pm 4.5$ & $5.9 \pm 2.6$ & $22.6 \pm 8.4$ & $20.6 \pm 10$ & $17.3 \pm 10$ \\
\hline
\end{tabular}

SD: Standard deviation.

Results shown are mean士SD from 2 marmosets as shown in Figure 5. 


\section{Supplementary Figure Legends}

\section{Supplementary Figure 1. Levels of DENV RNA in primary or re-challenge} DENV-infected marmosets. Data for these graphs was extracted from the study of Omatsu T. et al. (2011). Marmosets were subcutaneously infected with the DENV-2 Mal/77/08 strain or with the DENV-2 DHF0663 strain. The vRNAs were detected in plasma by real-time PCR. (a) Cj08-007, Cj07-011: Mal/77/08 strain (1.9x105 PFU/ml). At the primary DENV infection, two marmosets were inoculated subcutaneously in the back with $1.9 \times 10^{5}$ PFU of the DENV-2 Mal/77/08 strain. (b) Cj07-006, Cj07-008: DHF0663 strain $\left(1.8 \times 10^{4} \mathrm{PFU} / \mathrm{ml}\right)$. At the primary DENV infection, two marmosets were inoculated subcutaneously in the back with $1.8 \times 10^{4}$ PFU of the DENV-2 DHF0663 strain. (c) Cj07-007, Cj07-014: DHF0663 strain (1.8x105 PFU/ml). In the case of the DENV re-challenge study, two marmosets initially inoculated with $1.8 \times 10^{5}$ PFU of the DHF0663 strain were re-inoculated 33 weeks after the primary challenge with $1.8 \times 10^{5} \mathrm{PFU}$ of the same virus.

\section{Supplementary materials and methods}

\section{Animals}

All animal studies were conducted in accordance with the protocols of experimental procedures that were approved by the Animal Welfare and Animal Care Committee of the National Institute of Infectious Diseases, Japan, and the National Institute of Biomedical Innovation, Japan. A total of 6 male marmosets, weighing 258-512 g, were used. DENV infection status in marmosets was used from a previous study (Supplementary Figure 1) [2]. Marmosets were caged individually at $27 \pm 2{ }^{\circ} \mathrm{C}$ in $50 \pm 10 \%$ humidity with a $12 \mathrm{~h}$ light-dark cycle (lighting from 7:00 to 19:00) at Tsukuba 
Primate Research Center, National Institute of Biomedical Innovation, Tsukuba, Japan. All animals were fed twice a day with a standard marmoset diet supplemented with fruit, eggs and milk. Water was given ad libitum. The animals were in a healthy condition and confirmed to be negative for anti-dengue virus antibodies before inoculation with dengue virus [2].

\section{Cells}

Cell culture was performed as previously described [2]. Vero cells were cultured in Minimum Essential Medium (MEM, Sigma) with 10\% heat-inactivated fetal bovine serum (FBS, GIBCO) and $1 \%$ non-essential amino acid (NEAA, Sigma) at $37{ }^{\circ} \mathrm{C}$ in $5 \%$ $\mathrm{CO}_{2}$. C6/36 cells were cultured in MEM with $10 \% \mathrm{FBS}$ and $1 \%$ NEAA at $28{ }^{\circ} \mathrm{C}$ in $5 \%$ $\mathrm{CO}_{2}$

\section{Virus}

DENV strains were reported as previously described [2]. DENV type 2 (DENV-2), DHF0663 strain (Accession no. AB189122) strain was used for inoculation studies. The DENV-2, DHF0663 strain was isolated from a DHF case in Indonesia. The DENV-2, Mal/77/08 strain was isolated from imported DF cases from Maldives. The DENV-2 isolated clinical samples were propagated with C6/36 cells and were used within 4 passages on C6/36 cells. Culture supernatant from infected C6/36 cells was centrifuged at 3,000 rpm for $5 \mathrm{~min}$ to remove cell debris, and then stored at $-80{ }^{\circ} \mathrm{C}$ until use.

\section{Infection of marmosets with DENV}

In the challenge study, the profiling of the key adaptive and innate immune cells in the 
marmosets after serotype 2 of DENV (DENV-2) infection was examined. At the primary DENV infection, four marmosets were inoculated subcutaneously in the back with $1.9 \times 10^{5}$ plaque forming unit (PFU) of the DENV-2 Mal/77/08 strain (Cj08-007, Cj07-011) or with $1.8 \times 10^{4}$ PFU of the DENV-2 DHF0663 strain (Cj07-006, Cj07-008) [2]. In the case of the DENV re-challenge study, two marmosets initially inoculated with $1.8 \times 10^{5}$ PFU of the DHF0663 strain were re-inoculated 33 weeks after the primary challenge with $1.8 \times 10^{5} \mathrm{PFU}$ of the same virus (Cj07-007, Cj07-014) [2]. Blood samples were collected on days $0,1,3,7,14$, and 21 after inoculation and were used for virus titration and flow cytometric analysis. Inoculation with DENV and blood drawing was performed under anesthesia with $5 \mathrm{mg} / \mathrm{kg}$ of ketamine hydrochloride. Day 0 was defined as the day of virus inoculation. DENV viral loads in marmosets were used from a previous study (Supplementary Figure 1) [2].

\section{Titration of viral RNA in plasma}

Plasma samples were stored at $-80{ }^{\circ} \mathrm{C}$ until use. Viral RNA was isolated from plasma samples, using the High Pure Viral RNA Kit (Roche Diagnostics). Levels of dengue viral RNA were determined by TaqMan real time reverse transcriptase-PCR (TaqMan RT-PCR) as previously reported [1]. One PFU/ml of the DENV-2 DHF0663 strain from plasma samples was equivalent to $285 \pm 35.4$ copies $/ \mathrm{ml}$ with this method, and the detection limit was $5 \times 10^{3}$ copies $/ \mathrm{ml}$ in plasma samples.

\section{Supplementary References}

1. Ito M, Takasaki T, Yamada K, Nerome R, Tajima S, Kurane I (2004) Development and evaluation of fluorogenic TaqMan reverse transcriptase PCR assays for detection of dengue virus types 1 to 4. J Clin Microbiol 42:5935-5937 
2. Omatsu T, Moi ML, Hirayama T, Takasaki T, Nakamura S, Tajima S, Ito M, Yoshida T, Saito A, Katakai Y, Akari H, Kurane I (2011) Common marmoset (Callithrix jacchus) as a primate model of dengue virus infection: development of high levels of viremia and demonstration of protective immunity. J Gen Virol 92:2272-2280 


\section{Supplementary Fig. 1}
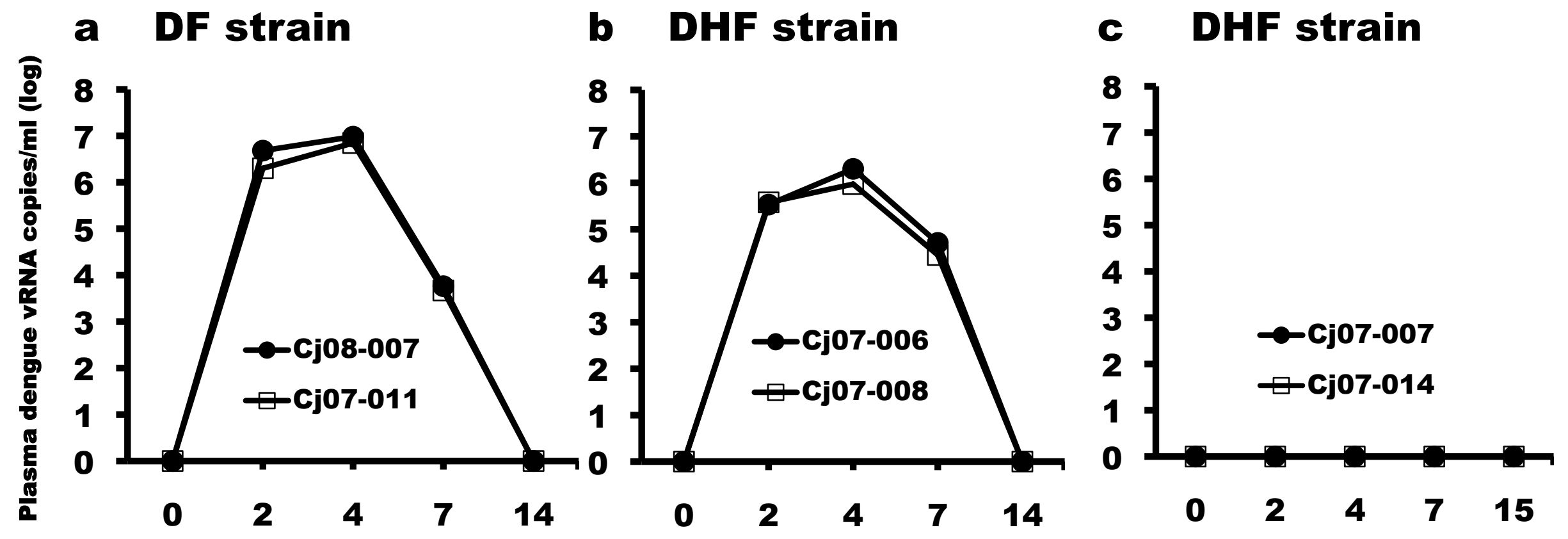

Days post inoculation 